Review

\title{
Genetic Neuropathy Due to Impairments in Mitochondrial Dynamics
}

\author{
Govinda Sharma ${ }^{1}$, Gerald Pfeffer ${ }^{2}$ (D) and Timothy E. Shutt ${ }^{1, *(D)}$ \\ 1 Departments of Medical Genetics and Biochemistry \& Molecular Biology, Cumming School of Medicine, \\ Alberta Children's Hospital Research Institute, Hotchkiss Brain Institute, University of Calgary, \\ Calgary, AB T2N 4N1, Canada; govinda.sharma@ucalgary.ca \\ 2 Departments of Clinical Neurosciences and Medical Genetics, Cumming School of Medicine, \\ Hotchkiss Brain Institute, Alberta Child Health Research Institute, University of Calgary, \\ Calgary, AB T2N 4N1, Canada; gerald.pfeffer@ucalgary.ca \\ * Correspondence: timothy.shutt@ucalgary.ca
}

check for updates

Citation: Sharma, G.; Pfeffer, G.; Shutt, T.E. Genetic Neuropathy Due to Impairments in Mitochondrial Dynamics. Biology 2021, 10, 268. https://doi.org/10.3390/biology 10040268

Academic Editor: G.

Angus McQuibban

Received: 24 February 2021

Accepted: 21 March 2021

Published: 26 March 2021

Publisher's Note: MDPI stays neutral with regard to jurisdictional claims in published maps and institutional affiliations.

Copyright: (c) 2021 by the authors. Licensee MDPI, Basel, Switzerland. This article is an open access article distributed under the terms and conditions of the Creative Commons Attribution (CC BY) license (https:// creativecommons.org/licenses/by/ $4.0 /)$.
Simple Summary: Mitochondria are organelles within our cells that are best known for their role in energy production. They are also able to fuse, divide, and move within the cell (referred to as mitochondrial dynamics). This is especially important in neurons, where cells can be very long as they travel in peripheral nerves to send signals to muscles or detect sensory stimuli. Problems with mitochondrial dynamics can result in a spectrum of human diseases, ranging from milder disease in late adulthood through to severe, lethal, early onset diseases. In this review, we discuss the important genes involved in mitochondrial dynamics that have also been connected with genetic neuropathies. We explain how these gene products interact to maintain normal mitochondrial functions and describe some common themes, such as mitochondrial quality control.

Abstract: Mitochondria are dynamic organelles capable of fusing, dividing, and moving about the cell. These properties are especially important in neurons, which in addition to high energy demand, have unique morphological properties with long axons. Notably, mitochondrial dysfunction causes a variety of neurological disorders including peripheral neuropathy, which is linked to impaired mitochondrial dynamics. Nonetheless, exactly why peripheral neurons are especially sensitive to impaired mitochondrial dynamics remains somewhat enigmatic. Although the prevailing view is that longer peripheral nerves are more sensitive to the loss of mitochondrial motility, this explanation is insufficient. Here, we review pathogenic variants in proteins mediating mitochondrial fusion, fission and transport that cause peripheral neuropathy. In addition to highlighting other dynamic processes that are impacted in peripheral neuropathies, we focus on impaired mitochondrial quality control as a potential unifying theme for why mitochondrial dysfunction and impairments in mitochondrial dynamics in particular cause peripheral neuropathy.

Keywords: neuropathy; mitochondria; mitochondrial dynamics; fusion; fission; transport; quality control

\section{Introduction}

\subsection{Mitochondrial Dynamics}

Mitochondria are highly active, double membraned organelles with many critical cellular functions. The term mitochondrial dynamics typically refers to the reciprocal processes of mitochondrial fusion and fission, which determine the morphology of the mitochondrial network. However, the term mitochondrial dynamics can also be expanded to include processes such as the transport of mitochondria [1], mitochondrial interactions with other organelles [2], as well as the biogenesis of new mitochondria, and the turnover of old or damaged mitochondria via mitochondrial autophagy (mitophagy) [3] or small mitochondrial derived vesicles [4]. Many of these dynamic processes are interrelated and 
depend on one another. For example, fission is required to generate fragments that are small enough to be degraded by mitophagy, or to move about the cell prior to fusing with other mitochondria. These dynamic processes allow mitochondria to adapt to physiological cues and are critical in maintaining cellular energetics, $\mathrm{Ca}^{2+}$ signaling, lipid biogenesis, mitochondrial quality control, and cell survival.

\subsection{Mitochondrial Dynamics in Neurological Disease}

The importance of mitochondrial dynamics is highlighted by the fact that mouse knockout models of essential genes that are required for fusion (MFN1, MFN2 and OPA1) or fission (DNM1L) result in mitochondrial dysfunction and embryonic lethality [5-9]. As such, it should come as no surprise that impairments to mitochondrial dynamics are increasingly recognized to play a role in disease [10], in particular those affecting the brain, and that targeting these processes is gaining traction as a promising therapeutic approach [11].

While mitochondrial dynamics are important for all cell types, they are of critical importance in neuronal cells, which have high energy requirements. In this regard, continuous fusion and fission ensures a homogenous distribution of mitochondrial contents and is necessary for efficient oxidative phosphorylation. Meanwhile, the unique cellular morphology of neurons, which comprise long axons, also contributes to their reliance on mitochondrial dynamics. Notably, while neuronal mitochondrial biogenesis and degradation were once believed to occur only in the cell body or soma of the neuron, there is emerging evidence for biogenesis and degradation occurring within axons [12]. Nonetheless, mitochondria still need to be transported to and from the sites of high ATP demand such as synapses, which are mostly located in distal regions of axons, often at extraordinary distances from the cell body. Thus, efficient intracellular transport and quality control mechanisms, in parallel with mitochondrial fusion and fission, are critical for neuronal cell function.

Supporting their importance in the brain, impaired mitochondrial dynamics have been associated with multiple neurodegenerative diseases such as Alzheimer disease, Huntington disease, Parkinson disease, etc. [13-15]. Parkinson disease, in particular, is linked to impairments in mitophagy [16]. Meanwhile, specific pathogenic variants in a number of essential fusion (OPA1 and MFN2) and fission (DRP1) proteins lead to various neuronal pathologies in humans, such as optic atrophy, peripheral neuropathy, and encephalopathy [17-20]. Additionally, a growing list of pathogenic variants have also been identified in other proteins that are also involved in mediating mitochondrial fusion (FBXL4, MSTO1) [21-23] or fission (MFF, MID49) [24,25]. In this review, we will focus on genetic neuropathy as a common phenotype often associated with impaired mitochondrial dynamics (Table 1).

\subsection{Genetic Peripheral Neuropathy}

Neuropathy occurs as part of the phenotype in numerous genetic diseases, either as a primary feature of the disease, or as part of a multisystem disorder. When neuropathy is the major feature of the clinical phenotype, the pattern of involvement allows categorization into one or more categories. When motor and sensory nerves are involved, this is referred to as hereditary motor and sensory neuropathy (HMSN), which is often used synonymously with Charcot Marie Tooth disease (CMT) [26]. Predominant motor involvement is referred to as hereditary motor neuropathy, or distal hereditary motor neuropathy (dHMN), which has substantial overlap with HMSN in its genetic causes [27]. Pure sensory involvement occurs in certain rare disorders referred to as hereditary sensory autonomic neuropathy (HSAN) [28]. Neuropathy can also occur as a feature in diverse genetic disorders with primary involvement of the nervous system, or in metabolic disorders. 
Table 1. Genes encoding proteins that regulate mitochondrial dynamics, and which are implicated in peripheral neuropathy phenotypes either as a primary feature or as an accompanying feature. Clinical classification according to OMIM (Online Medelian Inheritance in Man; www.omim.org, accessed on 1 November 2020). Mt denotes mitochondria, ER denotes endoplasmic reticulum, LD denotes lipid droplets, NMIIC denotes non-muscle myosin IIC.

\begin{tabular}{|c|c|c|c|}
\hline Gene & Protein Function(s) & Clinical Classification & Clinical Features \\
\hline \multicolumn{4}{|c|}{ Neurogenetic conditions with neuropathy as a primary clinical feature } \\
\hline MFN2 & $\begin{array}{l}\text { Mitochondrial fusion; Organelle } \\
\text { contacts (Mt-ER, Mt-LD); } \\
\text { Mitophagy. }\end{array}$ & $\begin{array}{l}\text { CMT2A2A (OMIM 609260) } \\
\text { CMT2A2B (OMIM 617087) } \\
\text { HMSN6A/CMT6A (OMIM 601152) }\end{array}$ & $\begin{array}{l}\text { Axonal sensorimotor peripheral } \\
\text { neuropathy; Optic atrophy; Hearing } \\
\text { loss; Lipomatosis. }\end{array}$ \\
\hline$S L C 25 A 46$ & $\begin{array}{l}\text { Negative regulator of } \\
\text { mitochondrial fusion. }\end{array}$ & CMT6B/HMSN6 (OMIM 601152) & $\begin{array}{l}\text { Axonal and demyelinating } \\
\text { sensorimotor peripheral neuropathy; } \\
\text { Optic atrophy; Ataxia; } \\
\text { Pontocerebellar hypoplasia; } \\
\text { Encephalopathy. }\end{array}$ \\
\hline GDAP1 & $\begin{array}{l}\text { Implicated in mitochondrial fission, } \\
\text { fusion, motility and ER contacts; } \\
\text { Peroxisome fission. }\end{array}$ & $\begin{array}{l}\text { CMT2K (OMIM 607831) } \\
\text { CMT2A (OMIM 214400/607706) } \\
\text { CMTRIA (OMIM 608340) } \\
\text { CMT4A (OMIM 214400) }\end{array}$ & $\begin{array}{l}\text { Axonal, intermediate and } \\
\text { demyelinating peripheral neuropathy; } \\
\text { Hoarseness (vocal cord paresis). }\end{array}$ \\
\hline DNM2 & $\begin{array}{l}\text { Implicated in mitochondrial fission; } \\
\text { Vesicle fission. }\end{array}$ & $\begin{array}{l}\text { CMT2B/CMTDIB (606482) } \\
\text { LCCS5 (615368) } \\
\text { CNM1 (160150) }\end{array}$ & $\begin{array}{l}\text { Peripheral neuropathy; } \\
\text { Neuromuscular syndrome; } \\
\text { Centronuclear myopathy. }\end{array}$ \\
\hline INF2 & $\begin{array}{l}\text { Actin regulator involved in } \\
\text { mitochondrial fission. }\end{array}$ & $\begin{array}{l}\text { CMTDIE (OMIM 614455) } \\
\text { FSGS5 (OMIM 613237) }\end{array}$ & $\begin{array}{l}\text { Intermediate peripheral neuropathy; } \\
\text { Glomerulosclerosis. }\end{array}$ \\
\hline $\begin{array}{l}\text { MYH14 } \\
\text { (NMIIC) }\end{array}$ & $\begin{array}{l}\text { Mitochondrial fission; Cytokinesis; } \\
\text { Cell motility; Cell Polarity. }\end{array}$ & $\begin{array}{l}\text { PNMHH (614369) } \\
\text { DFNA4A (600652) }\end{array}$ & $\begin{array}{l}\text { Axonal sensorimotor neuropathy; } \\
\text { Myopathy; Hoarseness; Hearing loss. }\end{array}$ \\
\hline KIF5A & $\begin{array}{l}\text { Mitochondrial anterograde } \\
\text { transport. }\end{array}$ & $\begin{array}{l}\text { SPG10 (OMIM 604187) } \\
\text { NEIMY (OMIM 617235) }\end{array}$ & $\begin{array}{l}\text { Spastic paraplegia; Peripheral } \\
\text { neuropathy; Myoclonic seizures. }\end{array}$ \\
\hline DYNC1H1 & Mitochondrial retrograde transport. & $\begin{array}{l}\text { CMT2O (OMIM 614228) } \\
\text { MRD13 (OMIM 614563) } \\
\text { SMALED1 (OMIM 158600) }\end{array}$ & $\begin{array}{l}\text { Peripheral neuropathy; Mental } \\
\text { retardation; Spinal muscular atrophy. }\end{array}$ \\
\hline \multicolumn{4}{|c|}{ Neurogenetic conditions having neuropathy as an accompanying (non-primary) feature } \\
\hline OPA1 & $\begin{array}{l}\text { Mitochondrial fusion; Cristae } \\
\text { organization. }\end{array}$ & $\begin{array}{l}\text { DOA/OPA1 (OMIM 165500) } \\
\text { DOA+ (OMIM 125250) } \\
\text { Behr Syndrome (OMIM 210000) } \\
\text { MTDPS14 (OMIM 616896) }\end{array}$ & $\begin{array}{l}\text { Optic atrophy; Optic neuropathy; } \\
\text { Auditory neuropathy; Axonal } \\
\text { sensorimotor peripheral neuropathy; } \\
\text { Encephalomyopathy; } \\
\text { Cardiomyopathy. }\end{array}$ \\
\hline $\begin{array}{l}\text { DNM1L } \\
\text { (DRP1) }\end{array}$ & $\begin{array}{l}\text { Mitochondrial fission; Peroxisome } \\
\text { fission. }\end{array}$ & $\begin{array}{l}\text { EMPF1 (OMIM 614388) } \\
\text { OPA5 (OMIM 610708) }\end{array}$ & $\begin{array}{l}\text { Encephalopathy; Seizures; Peripheral } \\
\text { neuropathy. }\end{array}$ \\
\hline MFF & $\begin{array}{l}\text { Mitochondrial fission; Peroxisome } \\
\text { fission. }\end{array}$ & EMPF2 (OMIM 617086) & $\begin{array}{l}\text { Encephalopathy; Microcephaly; } \\
\text { Seizures; Optic atrophy; Peripheral } \\
\text { neuropathy. }\end{array}$ \\
\hline
\end{tabular}

The most common presentation of genetic neuropathy is HMSN. This is a large group of genetic conditions causing progressive dysfunction of motor and sensory nerves. In general, nerves with the longest axons are affected first, producing a length-dependent clinical progression with earlier involvement of the feet and hands. The clinical presentation features symptoms and signs of motor dysfunction including atrophy and weakness of intrinsic muscles in the feet, lower legs, and hands. The longstanding nature of the disorder results in trophic changes in the feet, with distinctive clinical features including pes cavus (high arch) and hammer toes. Although sensory symptoms may be present, typically the motor features predominate in these conditions. Most cases of HMSN are disorders with the sole involvement of the peripheral nervous system; however, other areas of the nervous system (e.g., optic nerves, auditory system, or pyramidal tracts) may be affected [29,30], 
and the involvement of other organ systems may also occur [31,32]. Furthermore, the neurological deficits from HMSN also result in the secondary involvement of other systems, most commonly the skeletal system (for example, scoliosis [33] and orthopaedic injuries to the feet and ankles [34]) and respiratory system (due to phrenic nerve involvement [35], vocal cord paresis [36], or above-mentioned scoliosis).

The clinical classification of HMSN/CMT is an evolving area. Classification systems have been based upon clinical presentation, neurophysiologic findings, mode of inheritance, genetic etiology, molecular mechanism, and combinations of these [37]. A detailed discussion of classification systems is beyond the scope of this review, although in practical use it is common for neurologists to describe HMSN based on neurophysiologic features: demyelinating subtype, with reduced conduction velocity, or axonal subtype, with reduced amplitudes and motor-predominant findings. Cases may also be considered as intermediate when features of both demyelinating and axonal pathology are present [38]. This basic classification can be informative to correlate with clinical findings and is also useful in predicting the genetic differential diagnosis. HMSN has a prevalence of 1 in 2500 , with more than 80 genes recognized to cause peripheral neuropathy [32,39], although approximately $90 \%$ of all cases are attributable to lesions in only four genes (PMP22, MFN2, $M P Z$ and GJB1) [40] and the majority of diseases have autosomal dominant inheritance.

As mentioned above, neuropathy is also a feature of numerous other genetic conditions, and although a detailed discussion is beyond the scope of this work, the subject has recently been reviewed comprehensively [41]. One group of disorders relevant to the content of this review is the presence of neuropathy in numerous metabolic conditions, including mitochondrial disorders [42]. Neuropathy is a central feature of certain mitochondrial syndromes such as ataxia-neuropathy spectrum disorders [43], although neuropathy also occurs as a common feature in milder mitochondrial syndromes [44] and is an under-reported phenotype in patients with mitochondrial disease in general [45].

\subsection{Peripheral Neuropathy, Mitochondrial Dysfunction and Mitochondrial Dynamics}

In addition to genetic neuropathy, which is the focus of this review, mitochondrial dysfunction is clearly implicated in acquired neuropathy [46]. For example, oxidative stress resulting from physiological conditions such as diabetes [47], or from exogenous sources such as anti-cancer drugs that damage mitochondrial DNA, is associated with peripheral neuropathy [48-50]. However, the exact molecular mechanism underlying neuropathy, be it genetic or acquired, remains undetermined, in part because mitochondria have many cellular functions in addition to their role in generating ATP, and as many types of cellular dysfunction are linked to peripheral neuropathy. Nonetheless, a key aspect of mitochondrial function that has been implicated in causing peripheral neuropathy is mitochondrial dynamics [51].

The prevailing theory explaining why impairments in mitochondrial dynamics lead to a peripheral neuropathy phenotype is via reduced mitochondrial motility. The reason being that mitochondrial transport is required for the proper distribution of mitochondria (Figure 1), which is especially important in neurons, as synapses require a continuous and high supply of ATP $[15,52,53]$. Moreover, the fact that peripheral nerves are very long is thought to make them especially susceptible to reductions in mitochondrial transport. Supporting this idea, the inhibition of both fission and fusion is known to reduce mitochondrial transport [15]. While fission is important to generate mitochondria that are small enough to transport easily, it is less clear why reductions in fusion impair transport. However, recent work suggests the existence of a mitochondrial transport checkpoint that evaluates mitochondrial function prior to allowing axonal transport [54]. As such, dysfunctional mitochondria, which may result from reduced fusion, may be prevented from anterograde axonal transport. 


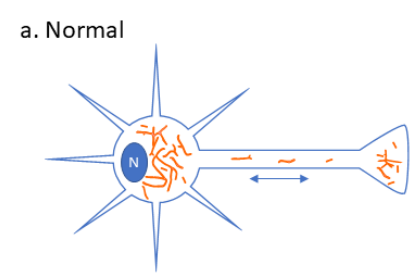

d. No anterograde transport

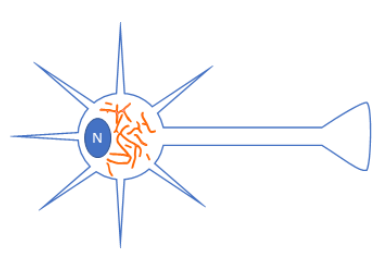

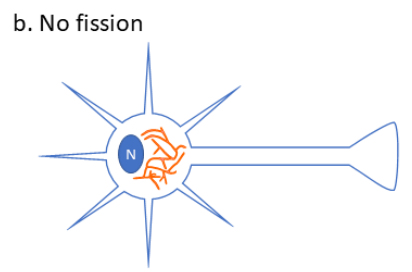

e. No retrograde transport

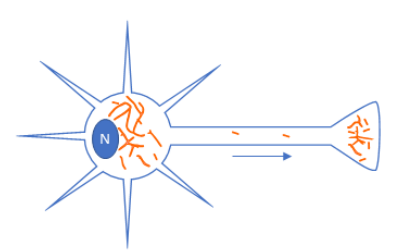

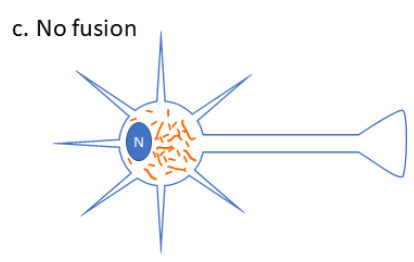

f. No fission at periphery

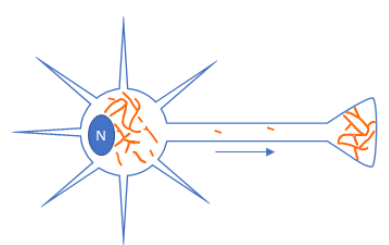

Figure 1. Impact of impairment to mitochondrial dynamics on neuronal mitochondrial transport. (a) In a healthy neuron, a variety of mitochondrial morphologies are present and both anterograde and retrograde transport occur. (b) In neurons with globally compromised mitochondrial fission, transport is impaired and hyperfused mitochondria remain in the cell soma. (c) In neurons with compromised mitochondrial fusion, fragmented mitochondria remain in the cell soma, and their transport is impaired. (d) In a neuron with functionally impaired anterograde transport, mitochondria are retained in the soma. (e) In neurons with impaired retrograde transport, mitochondria can move down axons and accumulate at the periphery. (f) In neurons where mitochondrial fission is impaired in distal regions (e.g., the R941L pathogenic variant of NMIIC), mitochondria are hyperfused at the cell periphery, and retrograde transport is compromised.

In addition to mitochondrial transport, mitochondrial dynamics impact a number of other cellular functions that are also relevant for peripheral neuropathy. For example, impaired interactions between mitochondria and the endoplasmic reticulum (ER), which regulate calcium signaling and lipid metabolism, have also been linked to peripheral neuropathy [55-59]. Similarly, mitochondria can regulate the formation and utilization of lipid droplets [60], the impairment of which is associated with peripheral neuropathy [61-63]. Here, we will review the dynamic processes of mitochondrial fission, fusion and movement, focusing on specific pathogenic variants in key proteins mediating these functions that are linked to peripheral neuropathy. In addition, we will highlight how these proteins impact other aspects of mitochondrial dynamics that are relevant to peripheral neuropathy. Finally, we will also discuss mitochondrial quality control as an unappreciated aspect of mitochondrial dynamics that is relevant to peripheral neuropathy.

\section{Pathogenic Variants in Proteins Mediating Mitochondrial Dynamics That Cause Peripheral Neuropathy}

\subsection{Mitochondrial Fusion}

Mitochondrial fusion is a multistep process that begins with the fusion of the outer mitochondrial membrane (OMM), and which is often followed by the fusion of the inner mitochondrial membrane (IMM) (Figure 2), though these events can be separated functionally. The fusion of the OMM is performed by the mitofusin proteins, MFN1 and MFN2, two homologous dynamin related GTPases that are integral to the OMM [64]. Homodimeric or heterodimeric interactions between MFN1 and MFN2 can tether adjacent mitochondria and mediate their fusion [65]. Although pathogenic variants in MFN2 are one of the major genetic causes of neuropathy, it is somewhat surprising that none have been described in MFN1. The current reasoning for this discrepancy is that the loss of MFN1 function can be compensated somewhat by MFN2. However, as MFN1 is not highly expressed in the nervous system, it cannot rescue the loss of MFN2 functions, which also partially explains why MFN2 dysfunction causes neuronal pathologies. However, as discussed later, we will see that MFN2 also has additional cellular roles, the impairment of which may also explain why pathogenic variants are found in MFN2, but not MFN1. 


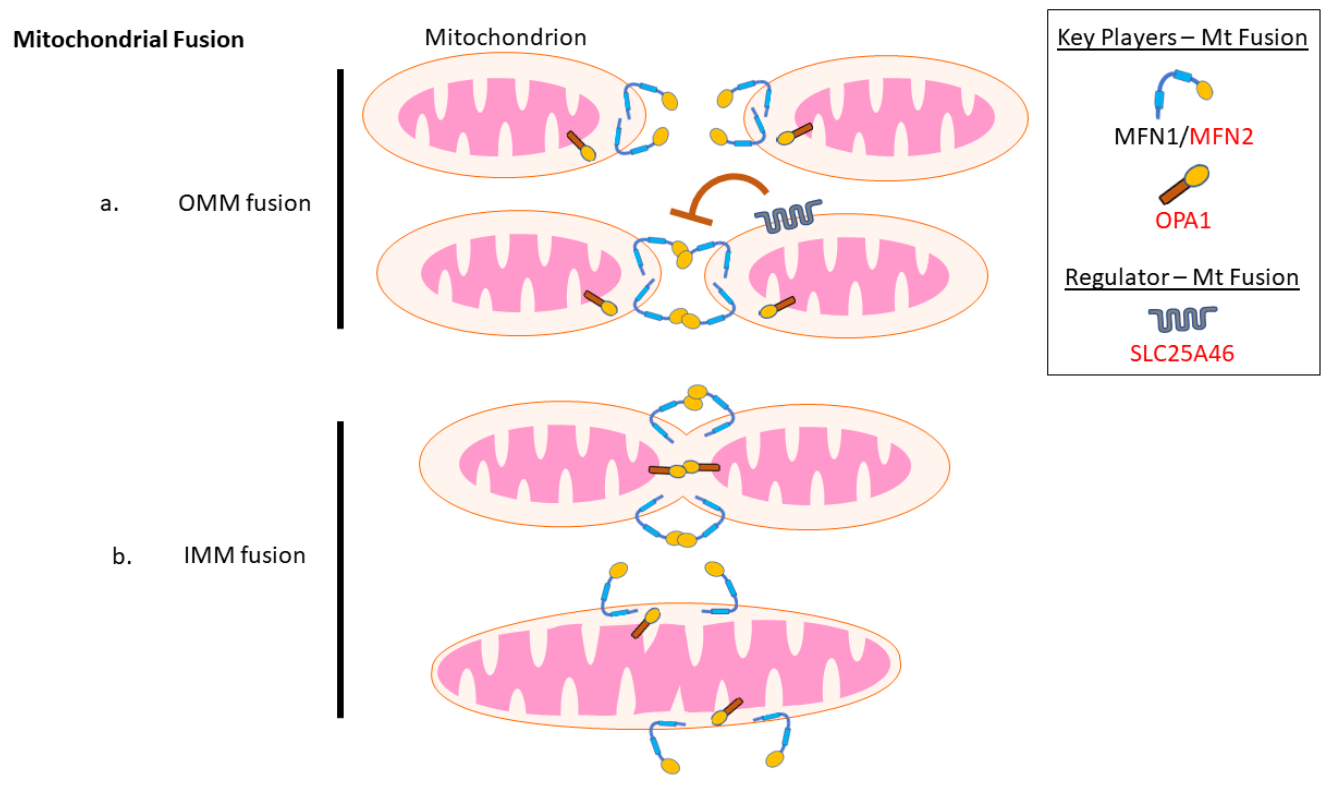

Figure 2. Key mitochondrial fusion players implicated in peripheral neuropathy. Mitochondrial fusion proceeds in two major steps. Proteins highlighted in red are linked to peripheral neuropathy phenotypes (a) MFN2, variants in which cause CMT2A, along with its homolog MFN1, mediate tethering and fusion of the outer mitochondrial membrane (OMM). Another OMM protein linked to peripheral neuropathy, SLC25A46, inhibits the actions of MFN1/2. (b) The inner mitochondrial membrane (IMM) protein OPA1 carries out IMM fusion. Though best known for autosomal dominant optic atrophy, pathogenic variants in OPA1 can also cause peripheral neuropathy.

Meanwhile, IMM fusion is mediated by another dynamin-like GTPase, optic atrophy 1 (OPA1), which is integral to the IMM [66]. In contrast to OMM fusion where mitofusins must be present on both opposing membranes, OPA1 can mediate fusion in vitro when present on a single membrane, though the mitochondrial specific phospholipid cardiolipin must to be present on the opposing membrane [67-69]. In addition to these core fusion proteins, a number of other protein factors (many of which have other cellular roles) have been implicated in mediating mitochondrial fusion, including cytosolic factors such as BAX [65] and MSTO1 [21,22], regulators of mitochondrial lipids such as MitoPLD [70], MIGA1 and MIGA2 [71], as well as various other proteins such as FBXL4 [23], ELMOD2 [72], and ARL2 [73]. Here, we focus specifically on MFN2 and OPA1, as pathogenic variants in these genes are clearly related to a peripheral neuropathy phenotype. Additionally, we will examine SLC25A46, which has been described as a negative regulator of mitochondrial fusion $[74,75]$. Though not discussed in detail here, it should also be noted that motor neuron damage was also recently reported in a single patient with pathogenic variants in MSTO1 [76].

\subsubsection{MFN2}

Mitofusins contain a GTPase domain, and two heptad repeat domains that are separated by a transmembrane domain. While it was long thought that the $\mathrm{N}$ - and $\mathrm{C}$ - termini of MFNs were both exposed to the cytosol, recent work suggests that the C-terminus is in fact exposed to the inner membrane space (Mattie et al., 2018). This new understanding of the topology of MFNs has important implications for several of the proposed MFN2 3D structures that have been solved or modelled to date [77-80]. Critically, these structures are from artificial MFN constructs that lack the transmembrane domain, allowing HR1 and HR2 domains to interact, which would not be the case in vivo. As such, the structural insight from these models is somewhat limited.

MFN2 is a multifunctional protein with several additional roles apart from mitochondrial fusion, including mediating interactions between mitochondria and other organelles (e.g., endoplasmic reticulum (ER), lipid droplets), mitochondrial transport, mitophagy, 
and even a direct role in lipid transfer to mitochondria. Despite being one of the first additional MFN2 functions to be described, there are still questions about how MFN2 mediates interactions between mitochondria and the ER. While the loss of MFN2 was initially shown to reduce Mt-ER contacts [81], recent observations suggest an increase in Mt-ER contacts [82,83]. While the debate on the role of MFN2 continues [84,85], and it is not clear why this discrepancy exists, the end result is that MFN2 clearly plays a role in mediating Mt-ER contacts. Notably, these contacts between mitochondria and ER (De Brito and Scorrano, 2008) are important in maintaining $\mathrm{Ca} 2+$ homeostasis and the exchange of lipids such as phosphatidylserine and cholesterol (Csordás et al., 2018; Krols et al., 2016). More recently, MFN2 was also shown to be involved in mediating interactions between mitochondria and lipid droplets via direct interaction with perilipin, a lipid droplet surface protein (Boutant et al., 2017). The functional relevance of this contact is shown by a recent report showing that the loss of MFN2 in adipocytes leads to an obese phenotype in mice (Mancini et al., 2019). MFN2 is also necessary and directly involved in mitochondrial transport, as it interacts with the Miro/Milton complex that links mitochondria to molecular motors, and the deletion of MFN2 leads to impairment in mitochondrial transport [86,87]. Finally, MFN2 plays a role in mediating mitophagy, as it is directly ubiquitinated by PARKIN [88-90] and the loss of MFN2 prevents PARKIN-mediated mitophagy [91].

MFN2 was one of the first mitochondrial dynamics proteins linked to peripheral neuropathy [92], with pathogenic variants being the leading cause of autosomally inherited axonal CMT. Over 100 mutations in MFN2 have been reported to be associated with peripheral neuropathy [93], including examples of both autosomal dominant and recessive inheritance (including semi-dominant inheritance). MFN2-related disease is highly variable in its severity, ranging from severe, early-onset neuropathy [94] to very late-onset presentations with low levels of disability [95]. Furthermore, MFN2 mutations can be associated with complex phenotypes in addition to peripheral neuropathy, which occur more commonly with recessive mutations. These phenotypes can include optic atrophy [96,97], hearing loss [96], central nervous system involvement [98], lipomatosis [99-101], and ataxia [102]. Given the well-defined role of MFN2 in mediating mitochondrial fusion, it is often assumed that impaired fusion is the primary cause of peripheral neuropathy. However, some MFN2 variants do not have any reported effect on mitochondrial morphology $[57,103,104]$, while other variants actually enhance fusion $[105,106]$. Thus, the mechanism linking MFN2 dysfunction to peripheral neuropathy is likely not solely due to reduced fusion. In this regard, pathogenic variants in MFN2 have also been shown to impair a number of the other cellular functions mediated by MFN2, including: Mt-ER contacts [57,58,81], mtDNA copy number [97,107,108], lipid metabolism [100], lipid droplets [57], mitochondrial respiration [109], and mitochondrial transport [110]. Notably, altered mitochondrial distribution, including reduced transport and clumping in the cell body, has been described for a number of MFN2 variants (V69F, L78P, R94Q, P251A, R280H and W740S) when expressed in culture rat dorsal root ganglion neurons [110], and is considered to be a major contributing factor to CMT2A pathology [111]. Nonetheless, it is difficult to causally link specific MFN2 dysfunctions with patient phenotypes, as only a few pathogenic variants have been studied functionally, and none have been studied systematically for all known MFN2 functions. Given the multifaceted roles of MFN2 and above-mentioned broad clinical variability, it is also possible that a combination of functions contributes to pathology. Excitingly, small molecules designed to activate MFN2, which restore mitochondrial morphology and motility, have recently been shown to overcome CMT2A mutants in reprogrammed patient motor neurons and in a mouse model $[112,113]$. While it remains to be determined how this molecule affects other MFN2 functions, it certainly offers a promising therapeutic option.

\subsubsection{Optic Atrophy 1 (OPA1)}

Like many mediators of mitochondrial morphology, OPA1 also contains a dynaminlike GTPase domain. Alternative splicing can generate multiple isoforms of OPA1, which can be processed into long and short isoforms (1-OPA1 and s-OPA1) via proteolytic process- 
ing inside of mitochondria. [114,115]. The processing of 1-OPA1 to short forms is induced by a reduction in mitochondrial membrane potential, as well as apoptotic signaling or stresses that induce fission [116]. While 1-OPA1 isoforms are essential for fusion, the exact role of the s-OPA1 isoforms remains debated, as they have been implicated in mediating both fusion and fission of the IMM [117,118]. In addition to its role in mitochondrial dynamics, OPA1 has been implicated in binding the mtDNA $[119,120]$ and is also important for maintaining cristae junctions $[18,118]$. Recent crystal structures of OPA1 have begun to provide a mechanistic basis for how OPA1 can potentially mediate both fusion and fission of the IMM [121,122].

Given the critical role of OPA1 in mitochondrial dynamics and maintenance, it is unsurprising that the deleterious genetic variations present pathologic phenotypes. The most well-studied pathology associated with OPA1 is autosomal dominant optic atrophy (ADOA), where heterozygous pathogenic variants in OPA1 account for over $>60 \%$ of patients with this phenotype $[123,124]$, and can also cause phenotypes such as optic neuropathy [124], auditory neuropathy [125,126], and peripheral neuropathy $[125,127]$. Based on the largest described series of OPA1-related ADOA [128], peripheral neuropathy is present in approximately $30 \%$ of patients, and is axonal with predominant sensory involvement. The neuropathy commonly co-exists with myopathy and/or ataxia. In general, neuromuscular involvement with ADOA has much later onset (3rd decade) than the ocular features (usually 1st decade), for reasons that are not understood.

In addition to dominant pathogenic variants that cause ADOA, compound heterozygous OPA1 variants are associated with more severe phenotypes. These phenotypes often include peripheral neuropathy, and can present with severe, early, multisystem involvement, such as Behr syndrome, mitochondrial depletion syndrome, or Leigh-like syndrome [129-136]. As a comprehensive understanding of exactly how OPA1 dysfunction causes these varying phenotypes is lacking, the mechanism responsible for peripheral neuropathy specifically remains uncertain. However, it is notable that OPA1 has been implicated in the proper distribution of mitochondria in neurons $[54,137,138]$. Meanwhile, pathogenic variants in OPA1 lead to the dysregulation of mitophagy $[54,131,139,140]$, with increased mitophagy reported in some dominant negative [131] and biallelic [140] OPA1 variants. Meanwhile, haploinsufficiency variants, including some linked to a peripheral neuropathy phenotype, showed reduced mitophagy [131,139]. These observations suggest that impaired movement and reduced mitophagy may be relevant to the peripheral neuropathy phenotype.

\subsubsection{SLC25A46}

SLC25A46 is a member of solute carrier family 25 (SLC25) of proteins that consist of three tandem homologous repeats of about 100 amino acids, with each repeat containing two hydrophobic transmembrane regions [141]. While the members of the SLC25 family of proteins are typically integral membrane proteins that transport molecules across the IMM [142], SLC25A46 is present on the OMM and is not believed to have transport activity [143]. Instead, SLC25A46 interacts with proteins involved in mitochondrial dynamics, most notably MFN2 and OPA1 [74,75]. Unexpectedly, SLC25A46 was recognized to be homologous to the yeast protein UGO1, which promotes mitochondrial fusion [143]. However, while SLC25A46 also impacts mitochondrial shape, its loss or impairment stabilizes MFN1/2 leading to hyperfused mitochondrial networks [75]. As such, SLC25A46 is considered to be a negative regulator of mitochondrial fusion. In addition, SLC25A26 has been implicated in mediating mitochondrial cristae dynamics and lipid homeostasis [74].

Pathogenic variants of SLC25A46 are associated with several pathologies previously linked to impaired mitochondrial dynamics. Initially described in patients with an optic atrophy spectrum disorder (including axonal sensorimotor neuropathy) [143,144], SLC25A46 variants are also linked to Leigh syndrome [74], progressive myoclonic ataxia with neuropathy [145], cerebellar ataxia [146], pontocerebellar hypoplasia [147,148] and Parkinson Disease [149]. Several animal models, including mouse [150-153], zebrafish [143], and 
Drosophila [154], also have neurologic phenotypes that recapitulate human disease. In addition to altered cristae structure and impaired bioenergetics, these animal models show mitochondrial impairment with enlarged mitochondria that have abnormal distribution and which colocalize with the autophagy marker LC3B, consistent with impaired mitophagy. Notably, SLC25A46 knockout mice have peripheral neuropathy with axonal degeneration and demyelination [152]. Pathogenic variants in SLC25A46 can be divided into two classes, those that destabilize the protein and those that alter molecular interactions [155]. Variants that result in the lowest levels of protein expression correlate with the most severe patient phenotypes. The peripheral neuropathy phenotype, which is present in most patients with pathogenic SLC25A46 variants, is thought to be due to a combination of increased fusion leading to hyperfused mitochondrial networks and altered mitochondrial distribution.

\subsection{Mitochondrial Fission}

Fragmentation of the mitochondrial network is critical for the generation of smaller mitochondrial fragments that can be separated from the larger mitochondrial network (Figure 3). As mitophagy cannot degrade larger mitochondria [156,157], fission is essential for mitochondrial quality control, as it facilitates the segregation for the removal of damaged mitochondria. Similarly, fission is required for the generation of smaller mitochondria that can then be transported throughout the cell. For example, the mitochondrial network fragments during the cell cycle, facilitating the distribution of mitochondria into daughter cells [158]. The primary mediator of mitochondrial fission is DRP1, a cytosolic dynamin-like GTPase that forms an oligomeric ring around mitochondria that constricts to mediate mitochondrial division $[159,160]$. Notably, while examples of DRP1-independent fission have also been reported [161-166], there is little known about how this process is mediated.

There are also several other critical factors that mediate mitochondrial fission. The first step in mitochondrial fission is a pre-constriction of mitochondria that is mediated by the ER wrapping around mitochondrial tubules [167] in order to constrict tubules sufficiently for DRP1 oligomers to assemble into rings [168]. Importantly, the force for this initial ER-mediated constriction is generated by the actin-myosin cytoskeleton. Two key regulators of this constriction are the actin-nucleating protein Spire1C present on mitochondrial membrane [169], and the actin polymerizing protein inverted formin2 (INF2) present on ER membrane [170]. Together, these two proteins mediate the formation of actin filaments around mitochondria [171], which then interact with Non-Muscle Myosin II (NMII) proteins to exert a force required for constriction [167,168]. Notably, all three NMII homologs (NMIIA, B, and C) have been implicated in mediating mitochondrial fission $[172,173]$.

Next, there are several distinct proteins anchored to the OMM that help mediate DRP1 recruitment and assembly for mitochondrial fission [174-176]. The first DRP1 adaptor to be identified was Fis1 (Fission factor1) [177,178]. Although Fis1 is essential for fission in yeast, it appears to be dispensable in mammalian cells $[179,180]$. Nonetheless, Fis1 has been implicated is fission events linked to certain stresses [181], as well as also mediating mitophagy [182,183]. Meanwhile, MFF (mitochondrial fission factor) as well as MID49 and MID51 (mitochondrial division proteins of 49 and 51kDa, respectively) seem to play more prominent roles in mediating fission, as their loss leads to hyperfused mitochondrial networks $[179,184,185]$. Finally, GDAP1 (Ganglioside-induced Differentiation-Associated Protein 1) has also been implicated in mediating mitochondrial fission [186,187], possibly via DRP1 recruitment. Importantly, there is still much to be learned about these distinct adaptors and their relative roles in mediating mitochondrial fission. In addition to mediating mitochondrial fission in response to different physiological signals, another possibility is that different adaptors have tissue-specific roles. In this regard, it may be notable that a pathogenic variant MID49 is associated with an isolated mitochondrial myopathy, without any neuropathy phenotypes [25]. Meanwhile, two dominant pathogenic variants 
in MID51, which cause impaired fusion/fission dynamics, were recently linked to optic neuropathy [188].

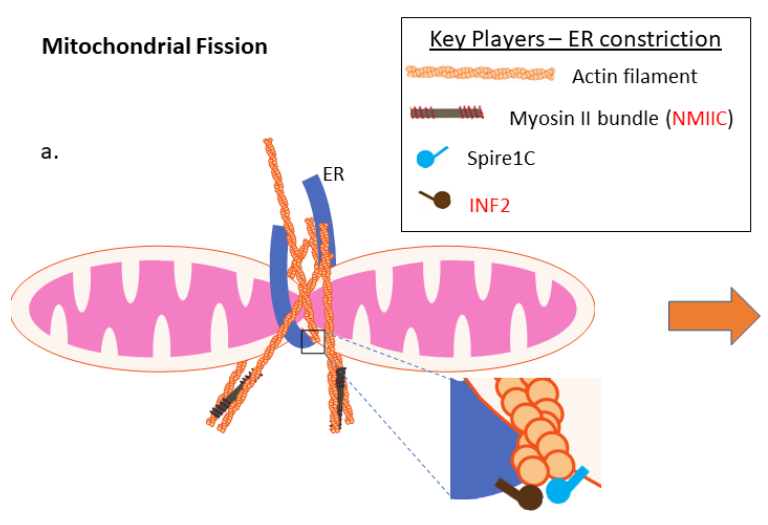

d.

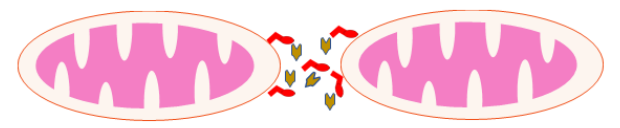

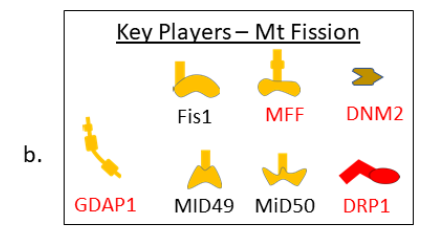
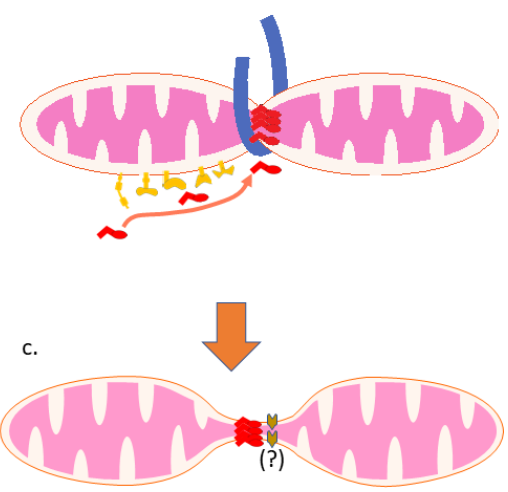

Figure 3. Key mitochondrial fission players implicated in peripheral neuropathy. Mitochondrial fission is a multistep process mediated by several factors. Protein names highlighted in red are linked to peripheral neuropathy phenotypes. (a) ER wrapping around mitochondria provides constriction at prospective fission sites that is mediated by actin/myosin motors. Key regulators of this actin-myosin constriction include ER-localized INF2 and mitochondrial-localized Spire1C. Notably, pathogenic variants in INF2 cause peripheral neuropathy and glomerulosclerosis, while a pathogenic variant in MYH14, encoding the NMIIC myosin protein, causes peripheral neuropathy and hearing loss. (b) Next, several outer mitochondrial membrane (OMM) proteins (e.g., MFF, MID49/50, and FIS1) act as adaptors that recruit the DRP1 fission protein, which oligomerizes to form a ring around mitochondria. Importantly, pathogenic variants in MFF and DRP1 can cause a variety of neuronal pathologies including peripheral neuropathy. Meanwhile, pathogenic variants in GDAP1, which is also present on the OMM and regulates fission, cause CMT4. (c) The oligomeric DRP1 ring tightens to further constrict the mitochondria to set up scission. Though not essential, DNM2 has been also implicated in the final constriction step and is known to harbor pathogenic variants that cause peripheral neuropathy. (d) Scission of the constricted mitochondrial tubule leading to the pinching off the two daughter mitochondria.

The final step in mitochondrial fission is the scission of the mitochondrial membranes. Structural models suggest that DRP1 can only constrict mitochondrial tubules down to about $50 \mathrm{~nm}$, and it is unclear whether this distance is sufficient to completely sever mitochondria or whether other factors are involved. One protein implicated in this final step, DNM2, was initially proposed to be essential for completing fission [189] as it colocalizes on the OMM with DRP1 puncta, and as its knockdown leads to hyperfused mitochondrial networks with constricted regions enriched in DRP1. However, two subsequent studies showed that mitochondrial fission can still occur in knockout cells lacking DNM2, as well as DNM1 and DNM3 $[190,191]$. While these studies suggest that DRP1 is sufficient for completing mitochondrial fission, the reduced fission in the DNM2 knockout cells [191] and knockdown cells [189] suggests a role for DNM2 in mediating mitochondrial fission, even if it is not essential.

\subsubsection{Ganglioside Induced Differentiation Associated Protein 1 (GDAP1)}

GDAP1 is anchored in the OMM via a c-terminal trans-membrane domain [186,192]. While GDAP1 harbors two glutathione S-transferase (GST) domains, initial reports suggested that GDAP1 does not possess GST activity $[193,194]$. However, more recent work showed that GDAP1 does have active GST activity [195], which is implicated in redox regulation [195-197]. Notably, GDAP1 forms homodimers and induces membrane curvature [195]. Though first recognized for its role in promoting mitochondrial fission [186], 
GDAP1 also mediates peroxisomal fission [198]. In addition, GDAP1 regulates mitochondrial fusion [187], is implicated in the regulation of Mt-ER interactions [199,200], and also impacts mitochondrial distribution [200], potentially via interactions with the cytoskeleton [201] or trafficking molecules such as RAB6B and caytaxin [199].

GDAP1 was one of the first regulators of mitochondrial dynamics linked to peripheral neuropathy, and mutations in this gene are the most common cause of autosomal recessive axonal CMT (CMT4A) [40], although intermediate or demyelinating neurophysiologic findings are also well-described [202,203]. Autosomal dominant inheritance is seen in cases with milder, axonal pathology and incomplete penetrance [204]. The disease onset is typically in childhood and commonly has distinctive phenotypic features including vocal cord paresis and proximal weakness. GDAP1-related diseases are more common in Spanish and Finnish populations due to founder effects [205,206].

Given that GDAP1 is expressed in both Schwann cells and neurons, it is likely that the impairment of both cell types can contribute to the pathology. Intriguingly, different pathogenic GDAP1 variants appear to cause peripheral neuropathy via different mechanisms [187]. Recessive variants, most of which are truncations lacking the C-terminal domain that anchors GDAP1 to mitochondria and cause severe early-onset disease, are associated with reduced mitochondrial fission. Meanwhile, dominant variants, which are primarily missense and lead to a milder pathology, cause reduced mitochondrial fusion leading to mitochondrial damage. Notably, pathogenic defects in GDAP1 do not seem to impair peroxisomal fission [198], suggesting peroxisomal impairment is not relevant to the disease phenotype. Further supporting the important role for GDAP1 in neurons, GDAP1 knockout models in mice [196,200,207], fish [208], and Drosophila [209] also recapitulate neurological dysfunction. Importantly, mouse knockout models show axonal neuropathy as well as demyelination, and also exhibit larger mitochondria with anomalous axonal distribution [196,200]. Additionally, GDAP1 knockout causes impaired mitochondrial bioenergetics and disturbed calcium signaling [200]. Notably, oxidative stress [196] and impaired mt-ER contacts [200] are also associated with GDAP1 dysfunction. Thus, there are multiple types of cellular dysfunction that likely contribute to peripheral neuropathy in patients with pathogenic variants in GDAP1.

\subsubsection{DRP1}

Dynamin related protein 1 (DRP1), encoded by the DNM1L gene, is a dynamin-like GTPase, which was initially shown to be involved in mitochondrial fission [210-212] and which also mediates peroxisomal fission $[213,214]$. The DRP1 protein comprises four main structural domains, the $\mathrm{N}$-terminal GTPase domain, the middle domain, the variable domain (also called insert B), and the C-terminal GTPase effector domain (GED).

Since the first report of a pathogenic variant in DNM1L [19], several pathogenic variants in DRP1 have been associated with highly variable neurological phenotypes [215-227], with some resulting in complex phenotypes and early mortality [19,228-231]. Meanwhile, a murine model harboring a mutation in DNM1L leads to cardiomyopathy [232], a common type of organ dysfunction in complex mitochondrial syndromes [233].

Pathogenic variants in DRP1 that cause reduced fission are located throughout the protein and can affect its activity in a variety of ways, including reduced GTPase activity [219] and impaired higher order assembly of DRP1 oligomers [228]. While epilepsy and encephalopathy are common among patients with pathogenic variants in DNM1L, there are also reports of peripheral neuropathy in some patients with heterozygous mutations in the GTPase domains $[219,221,234]$. Notably, patient fibroblasts harboring the D146N DRP1 variant that causes severe axonal neuropathy exhibit hyperfused mitochondria with reduced mitophagy [219]. Moreover, neuronal loss of DRP1 leads to the accumulation of larger mitochondria with abnormal distribution, consisting of the depletion of axonal mitochondria [235-237], while Drosophila models also show impaired mitochondrial trafficking when expressing pathogenic DRP1 variants [215,220]. Meanwhile, pain insensitivity, a feature consistent with peripheral neuropathy, has also been reported in two distinct patients 
with the same G362S heterozygous mutation in the middle domain of DRP1 [216,238]. While the G362S variant causes hyperfused mitochondria, it does not affect peroxisomal morphology, suggesting peroxisomal dysfunction may not be relevant to peripheral neuropathy. DRP1 has also been implicated in the pathogenesis of neuropathic pain in animal models [239]. Together, these observations implicate reductions in mitochondrial motility and mitophagy as likely contributing to the peripheral neuropathy phenotype.

\subsubsection{Mitochondrial Fission Factor (MFF)}

MFF plays an important role in both mitochondrial and peroxisomal fission [240] by mediating DRP1 recruitment. MFF is anchored to the OMM via its c-terminal transmembrane domain, while the N-terminal domain interacts directly with DRP1 [241]. As evidence of its key role in mediating mitochondrial fission, knockout of MFF prevents DRP1 recruitment to mitochondrial foci and leads to elongated mitochondria [179], comparable to that observed in DRP1 knockdown cells [240]. The phosphorylation of MFF by AMP kinase, a sensor of reduced ATP production and mitochondrial dysfunction [242], promotes mitochondrial fission [243], suggesting that MFF may help coordinate mitochondrial fission in response to energetic stress.

The importance of MFF for human health is highlighted by the fact that several pathogenic variants in MFF have recently been described [24,244-246]. The first report of a pathogenic variant in MFF was a truncating mutation in a patient with delayed psychomotor development, spasticity, Leigh-like encephalopathy and optic atrophy [244]. Meanwhile, other patients with truncating mutations in MFF have also been reported with similar phenotypes as well as peripheral neuropathy [24]. Further highlighting the importance of MFF, knockout mice showed neuromuscular defects, altered gait, decreased grasping ability and reduced fertility [247]. Intriguingly, while MFF -/- mice died at $\sim 13$ weeks from dilated cardiomyopathy caused heart failure, when crossed with MFN1 -/- mice, which die at embryonic stage, the double MFF -/-; MFN1 -/- mice do considerably better. This rescue elegantly demonstrates the importance of balance fission and fusion, and offers hope that rebalancing mitochondrial fission and fusion may be a viable therapeutic approach.

\subsubsection{Dynamin 2 (DNM2)}

DNM2 is an essential protein with many cellular roles, including receptor mediated endocytosis, membrane trafficking, and cytoskeleton regulation [248-250], which is embryonically lethal when knocked out in mice [251]. Like DRP1, DNM2 is a member of the dynamin family of large GTPases. It consists of a GTPase domain, a middle domain, a pleckstrin homology (PH) domain, a GTPase effector domain (GED), and a C-terminal proline/arginine-rich domain (PRD). While the PH domain is responsible for membrane binding, the GED functions as a GAP for GTPase activity and mediates the higher order assembly of DNM2.

Despite the fact that DNM2 does not appear to be essential for mitochondrial fission $[190,191]$, this does not mean that it is not involved in the process. Moreover, there could be certain cell types where DNM2 is more important for fission. In this regard, it is notable that pathogenic variants in DNM2 are well known to cause peripheral neuropathy [252-256], as well as centronuclear myopathy (CNM), characterized by weakness and slow progressive muscle loss [253,257-259]. Interestingly, DNM2 variants associated with peripheral neuropathy are mostly located in the membrane binding $\mathrm{PH}$ domain $[252,253,256]$. Meanwhile, variants present in other regions are associated with CNM, with occasional instances of co-existing neuropathy [252,256]. Studies of cell-type specific conditional DNM2 knockout mice provide interesting insight, with Schwann cell knockout resulting in cell death and rapid progression to peripheral neuropathy [260], while oligodendrocyte knockout does not cause significant effects in the CNS [260]. Furthermore, muscle cell specific DNM2 knockout mice had both enlarged mitochondria and increased numbers of lipid droplets, with altered neuromuscular junctions leading to 
peripheral nerve degeneration [61]. Overall, these cellular phenotypes are consistent with the notion that DNM2 variants impair mitochondrial fission, though this still needs to be confirmed experimentally.

\subsubsection{Inverted Formin 2 (INF2)}

INF2 is a member of the formin family of proteins that accelerate actin filament nucleation and elongation [261]. Alternative splicing leads to two isoforms of INF2, one of which is cytoplasmic and regulates the Golgi architecture [262], while the other is anchored to the ER via C-terminal anchors [263]. The ER-localized pool of INF2 regulates the actinmediated ER-constriction that initiates mitochondrial fission, as the loss of INF2 function leads to reduced numbers of mitochondria-ER contacts and less mitochondrial fission upon ionomycin stimulation $[264,265]$. In addition to the formin homology 1 (FH1) and 2 (FH2) domains that are characteristic of all formins [266], INF2 is regulated by autoinhibition mediated by the interaction between the C-terminal diaphanous autoregulatory domain (DAD) and N-terminal diaphanous inhibitory domain (DID), and is thus a member of "diaphanous formins" [267,268]. Interestingly, INF2 is unique among formins as it has been found to accelerate both the polymerization and depolymerization of actin filaments.

Genetic variants of INF2 are associated with autosomal dominant intermediate CMT and glomerulosclerosis, with sensorineural hearing loss commonly present $[269,270]$. The majority of the pathogenic variations in INF2 are localized to a region in the DID domain $[269,271]$, where they are thought to impair the inhibitory interaction with the DAD domain and render INF2 constitutively active [272]. In the context of mitochondrial morphology, the introduction of the A149D functional mutation in the DID region of INF2, which constitutively activates the protein, led to increased rates of mitochondrial fission and reduced mitochondrial length [170]. Importantly, this work showed that sequence changes in this region can indeed impact mitochondrial morphology. However, unlike other mitochondrial fission proteins linked to peripheral neuropathy, the impairment of INF2 may actually increase fission. Additionally, mitochondrial motility was also reduced in cells expressing the A149D mutation, which is also likely relevant to the peripheral neuropathy phenotype. Notably, recent work shows that like the A149D mutation, pathogenic variants in INF2 cause aberrant formin activity [273], suggesting they may have similar impacts on mitochondrial fission. Nonetheless, as INF2 has multiple isoforms and impaired actin function can impact several cellular functions, it is not clear exactly how pathogenic variants in INF2 cause disease. However, given the role of INF2 in regulating mitochondrial fission, and the fact that unbalanced mitochondrial dynamics and reduced motility are linked to peripheral neuropathy, it seems likely that pathogenic variants in INF2 affect mitochondrial fission [170], although this idea remains to be verified experimentally.

\subsubsection{Non Muscle Myosin II C (NMIIC)}

Non muscle myosin family II proteins are expressed in all cell types, where they are required for a variety of cellular functions mediated by actin-myosin generated force, including cytokinesis, cell migration, cell shape changes, the internalization of cell surface receptors and mitochondrial fission. There are three NMII family members in humans, NMIIA, NMIIB, and NMIIC, encoded by MYH9, MYH10 and MYH14, respectively. All three proteins are believed to be able to form homo or heterodimers with partially redundant functions. Importantly, most cell types express at least one or two NMII proteins, with neurons primarily expressing NMIIB and NMIIC [274]. Although NMIIA and NMIIB are the most studied members of the family and were the first members shown to be involved in mitochondrial fission [172], NMIIC was also recently shown to mediate this process [173].

A number of different loss of function pathogenic variants in MYH14 cause nonsyndromic autosomal dominant hearing loss [275-280]. However, a single pathogenic variant in MYH14, R941L, which was identified in several unrelated families, is linked to axonal peripheral neuropathy, myopathy, and hoarseness in addition to hearing loss $[173,275,281,282]$. 
It is most likely that the hearing loss in R941L patients is due to the loss of NMIIC function, as is the case with most other MYH14 variants. However, the R941L variant in NMIIC also has a dominant negative effect that impairs mitochondrial fission [173]. Notably, it remains to be determined whether or not MYH14 variants that are not associated with peripheral neuropathy also impact fission. Given that patient fibroblasts harboring the R941L variant have hyperfused mitochondrial networks, it is most likely that fission impairments are responsible for the peripheral neuropathy phenotype. It is also intriguing that mitochondrial networks at the cell periphery of MYH14 fibroblasts are resistant to fission, suggesting the NMIIC may have a specific role in this subcellular region. While additional validation is still required, one proposed mechanism is that hyperfused mitochondrial networks in the cell periphery could impair retrograde transport and/or mitophagy, contributing to the disease phenotype [283].

\subsection{Mitochondrial Transport}

Mitochondria are transported throughout the cell by an active process that is mediated by molecular motors and the cytoskeleton (Figure 4). In neurons, mitochondrial transport along axons is essential for proper function, as healthy mitochondria need to be mobilized to specific sites of high energy demand, while mitochondria also return to the soma [284]. Neuronal mitochondrial transport occurs along microtubules, with several kinesin proteins capable of moving mitochondria in an anterograde direction (towards the cell periphery), while dynein mediates retrograde mitochondrial transport (towards the nucleus from the cell periphery) $[285,286]$. Kinesin motors attach to mitochondria via adaptor complexes, the best characterized of which comprises either of the Miro1 or Miro2 homologs, which are atypical Rho GTPases present on the outer mitochondrial membrane, and either of the TRAK1 or TRAK2 homologs, which link Miro1/2 to kinesins. Meanwhile, the mechanism by which dynein interacts with mitochondria remains largely unknown, although TRAK2 has been implicated in dynein-mediated transport [287]. Above and beyond a role in mediating mitochondrial fission, the actin-myosin cytoskeleton can also mediate short range mitochondrial movement. For example, the OMM protein Myo19, which interacts with Miro proteins, can facilitate the transport of mitochondria over short distances along actin filaments [288]. Moreover, actin-myosin interactions can also anchor mitochondria in place and oppose dynein and kinesin-mediated transport [289].

Mitochondrial Transport
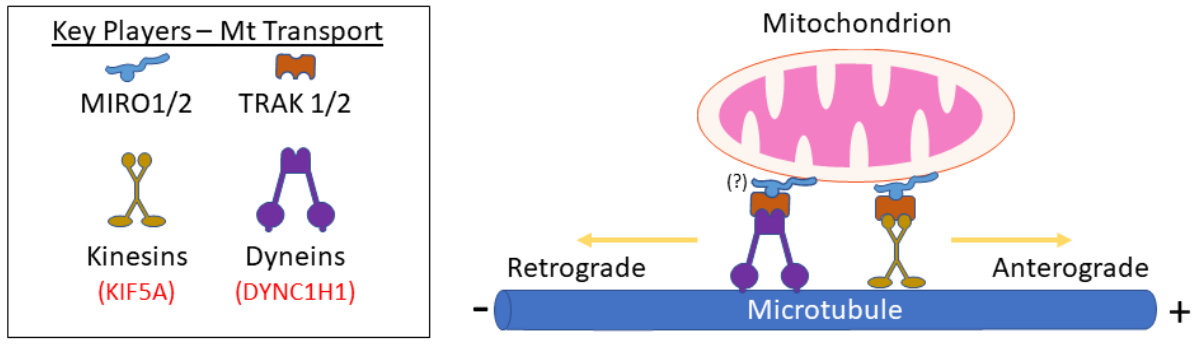

Figure 4. Key regulators of mitochondrial transport implicated in peripheral neuropathy. Anterograde and retrograde mitochondrial transport along the microtubule cytoskeleton is mediated by specific machinery. Protein names highlighted in red are linked to peripheral neuropathy phenotypes. The outer mitochondrial membrane homologs MIRO1 and MIRO2 interact with the homologous TRAK1 and TRAK2 adaptors. Kinesins, including the KIF5A implicated in hereditary spastic paraplegia and peripheral neuropathy, interact with TRAK1/2 to mediate anterograde mitochondrial transport (+). Meanwhile, retrograde mitochondrial transport $(-)$ is mediated by the dynein complex, including DYNC1H1, which is implicated in CMT2O.

In addition to the transport machinery described above, it is also worth noting that key mitochondrial fission and fusion proteins are also implicated in mitochondrial transport. For example, the loss of DRP1 impairs mitochondrial transport $[235,290]$. While this reduced motility is likely due to reduced fission and mitochondria being too large to move 
efficiently, it is also worth noting that DRP1 has been implicated specifically in dyneinmediated retrograde mitochondrial transport [291]. Meanwhile, MFN2 plays a direct role in motility via interaction with Miro/TRAK complexes, with reduced mitochondrial motility in cells lacking MFN2 [87]. Notably, several pathogenic MFN2 associated with peripheral neuropathy variants (e.g., V69F, L76P, R94Q, P251A, R280H, W740S) have been demonstrated to impair mitochondrial transport [110].

As discussed above, impaired global axonal transport is one of two main dysfunctions underlying peripheral neuropathies. The fact that the specific inhibition of mitochondrial transport seems to be sufficient to cause of peripheral neuropathy highlights the importance of these critical organelles. It is also worth noting that both anterograde and retrograde mitochondrial transport can be impaired in neurodegenerative diseases such as Alzheimer disease and amyotrophic lateral sclerosis (ALS) [292-294]. In Alzheimer disease, where mostly the CNS neurons are affected, optic neuropathy is more common [295,296]. Notably, optic neuropathy occurs in other neurodegenerative conditions with mitochondrial transport defects such as Parkinson disease [297] and Huntington disease [298]. Meanwhile, in ALS, which affects the peripheral motor neurons, peripheral neuropathy is common. In both cases, it is thought that impaired mitochondrial transport contributes to the neuropathy in these disorders. Here, we review pathogenic variants in the mitochondrial transport machinery that are associated with peripheral neuropathy.

\subsubsection{Kinesin}

Kinesins are a family of molecular motors that transport cellular cargo along microtubules. To date, 45 kinesin family (KIF) proteins have been identified in mammals and are categorized into 15 sub-families [299]. Among these KIF proteins, kinsein-1 subfamily members KIF5A, B and C (also known as kinesin heavy chain; KHC) are primarily responsible for mediating anterograde mitochondrial transport [300,301]. While KIF5B is expressed ubiquitously [300,302], KIF5A and KIF5C are predominantly expressed in neuronal cells, with KIF5A enriched in CNS and KIF5C enriched in motor neurons [302]. Meanwhile, kinesin-3 subfamily members KIF1B [303] and KLP-6 [304] are additional kinesins that can mediate anterograde mitochondrial transport.

In the context of disease, several pathogenic variants in KIF5A are associated with a disease spectrum ranging from upper motor neuron involvement to peripheral neuropathy [305]. The most common disease associated with KIF5A mutations is spastic paraplegia type 10, which may present as uncomplicated HSP (hereditary spastic paraplegia) or less commonly complicated HSP accompanied by various additional neurologic features [306]. When presenting as peripheral neuropathy, KIF5A-related disease is characterized by axonal sensorimotor neuropathy, but can variably include central nervous system involvement [305,307-312]. Supporting the role of KIF5A in mitochondrial transport, the expression of pathogenic KIF5A variants in both Drosophila [313] and zebrafish [314] models leads to reduced mitochondrial transport. Additionally, a single loss of function variant in KIF1B has been described in a family with peripheral neuropathy (CMT2A1), and heterozygous KIF1B - /+ mice exhibit chronic peripheral neuropathy and impaired synaptic vesicle transport [315]. However, it remains to be determined whether this KIF1B variant impairs mitochondrial transport or mitochondrial functions. Finally, pathogenic variants in the related protein KIF1A can also lead to peripheral neuropathy, among other neurological phenotypes [316-318], and are implicated in mitochondrial dysfunction [319,320]. However, a role for KIF1A in mediating mitochondrial transport has not been described, and reduced KIF1A expression does not impact mitochondrial motility [321]. Collectively, the recurrence of pathogenic variants in proteins that regulate mitochondrial transport suggests a common mechanistic underpinning.

\subsubsection{Dynein}

Dyneins are molecular motor complexes that mediate movement along microtubules in a retrograde direction. Retrograde mitochondrial transport is mediated by Dynein 1 (also 
called cytoplasmic dynein) [322], a heterologous complex made up of two dynein heavy chains (DHC), two dynein intermediate chains, two dynein light-intermediate changes, and various numbers of light chains [323,324]. While the DHC comprises an ATPase domain, a motor domain, a microtubule binding domain and a stem region that binds to intermediate and light chains $[325,326]$, the intermediate and light chains form a sub-complex that binds to various cellular cargo [327].

Dynein 1 impairment has been implicated in a spectrum of neurological diseases [328], with pathogenic variants in the DHC subunit DYNC1H1 linked to neuromuscular disorders including spinal muscular atrophy [329] and peripheral neuropathy [330], as well as mental retardation [331,332]. However, no pathogenic variants in other Dynein I components such as light, light intermediate or intermediate chains have been reported to cause peripheral neuropathy [333]. Notably, a pathogenic variant in DYNC1H1 has been linked to CMT2O, a finding that is supported by mouse models showing that nearby mutations in DYNC1H1 cause a sensory neuropathy phenotype $[334,335]$. Although the human pathogenic variant linked to peripheral neuropathy has not been characterized in the context of mitochondrial function or transport, fibroblasts from patients with DYNC1H1 variants causing spinal muscular atrophy exhibit fragmented morphology [336]. Meanwhile, the two mouse DYNC1H1 variants that have been described lead to mitochondrial fragmentation [336] and reduced mitochondrial retrograde transport [337]. Thus, it is expected that the pathogenic human DYNC1H1 variant causing peripheral neuropathy will also impair mitochondrial transport and morphology, though this remains to be confirmed.

\section{Mitochondrial Dynamics and Quality Control in Peripheral Neuropathy}

While impaired mitochondrial transport is typically thought to explain the peripheral neuropathy phenotype associated with pathogenic variants in genes regulating mitochondrial dynamics, there is likely more to the story. For example, while the length of peripheral axons is proposed to explain their sensitivity to reduced mitochondrial motility, the CNS axons of humans, which do not necessarily show degeneration when motility is impaired, can be longer than peripheral neurons in mice, which do exhibit peripheral neuropathy [338]. Thus, impaired transport down long neurons alone is insufficient to explain why peripheral neurons are sensitive to impaired mitochondrial dynamics.

Given that transport problems alone cannot explain why impaired mitochondrial dynamics cause peripheral neuropathy, we propose that mitochondrial quality control is an underappreciated aspect of mitochondrial dynamics that is also relevant to peripheral neuropathy. For example, mitochondrial fusion promotes content mixing, which can dilute the effects of mitochondrial damage $[64,339,340]$. Moreover, MFN2 is directly involved in mediating mitophagy [341,342]. Meanwhile, OPA1 has also been implicated in mitophagy [343], and pathogenic OPA1 variants alter mitophagy. Additionally, mitochondrial fission is also important for quality control as it is essential for mitophagy, due to the fact that large hyperfused mitochondrial networks are resistant to mitophagy $[156,157]$. Finally, mitochondrial transport itself, which depends on fusion and fission, is important for quality control in the context of delivering healthy mitochondria for fusion complementation and in potentially removing damaged mitochondria. However, while retrograde transport was once thought to be important for the degradation of mitochondria, there is now strong evidence that mitophagy occurs within axons [344] and that mitochondria are not necessarily transported to the soma for degradation [12]. Nonetheless, pathogenic variants that reduce mitochondrial fusion, fission and motility are all expected to negatively impact mitochondrial quality control, suggesting that quality control may be a unifying theme.

Intriguingly, pathogenic variants in many of the peripheral neuropathy proteins discussed here lead to hyperfused mitochondrial networks (e.g., SLC25A46, DRP1, MFF, GDAP1, MYH14). However, the example of MYH14 is especially interesting, given the possibility the impairing fission only at the cell extremity may be sufficient to cause peripheral neuropathy [173]. In this case, it would be expected that mitochondria could still be transported along axons in an anterograde direction, allowing fusion and content mixing. 
However, hyperfused mitochondria at the cell periphery would be resistant to retrograde transport and mitophagy (Figure 1f). Given the questions around the role of retrograde transport for degrading damaged mitochondria, this model would further highlight the role of axonal mitophagy for quality control and its impairment in peripheral neuropathy.

While there are multiple mechanisms mediating mitochondrial mitophagy, undoubtedly the best studied pathway is the PINK1-PARKIN pathway, which has been well characterized as rare pathogenic variants in PINK1 and PARKIN cause Parkinson Disease [345]. In addition to mediating mitophagy, PINK1 and PARKIN are also implicated in the production of mitochondrial derived vesicles (MDVs) that can be delivered to lysosomes [346]. As MDVs are generated independently of mitochondrial fission, they represent another distinct mitochondrial quality control pathway $[4,347]$. Notably, there is increased incidence of peripheral neuropathy in patients with Parkinson Disease [348-351], emphasizing the pathology of Parkinson Disease beyond the CNS.

In addition to mitophagy and MDVs, another recently described neuronal mitochondrial quality control mechanism that may be relevant to peripheral neuropathy is the release of axonal mitochondria into the extracellular space. Such mitochondrial expulsion has been described in the mammalian CNS [352], in C. elegans neurons [353], and has been observed in the context of stresses that damage mitochondria where it appears to complement mitophagy as a quality control mechanism [354]. Furthermore, in retinal ganglion cell axons, and likely throughout the CNS, these released mitochondria can be taken up by astrocytes where they can then be degraded in a process termed transmitophagy [352]. Unexpectedly, transmitophagy appears to be more prevalent than mitochondrial degradation in the soma, suggesting it is very relevant to axonal mitochondrial quality control. Conversely, astrocytes have also been shown to deliver presumably healthy mitochondria to neurons [355]. Thus, astrocytes clearly play an important role in maintaining neuronal mitochondrial quality control. While astrocytes can interact with myelinated axons [356], whether similar transmitophagy occurs in peripheral cells is unknown. However, given the distinct morphology of peripheral nerves, which are tightly packaged by Schwann cells, it is reasonable to assume that astrocytes would have restricted access to axons, and that transmitophagy could be of limited benefit. As such, peripheral nerves may depend more on local axonal mitophagy and retrograde transport of damaged mitochondria, which may partially explain why these neurons are more sensitive to impaired mitochondrial dynamics.

\section{Discussion}

In this review, we examined pathogenic variants in key proteins that mediate mitochondrial fusion, fission, and transport, and which cause peripheral neuropathy (Table 1). However, there are other examples of pathogenic variants causing peripheral neuropathy that also impact these dynamic mitochondrial processes (Table 2). Two examples worth briefly mentioning as they offer more concrete links to mitochondrial dynamics are RAB7 and ATL3. The small GTPase RAB7 is best characterized as an endosomal protein linked to CMT2B [357]. However, RAB7 has also recently been implicated in mitochondrial fission via mediating mitochondrial-lysosomal contacts [358,359] and actin dynamics [360], as well as impacting mitochondrial motility [359] and mitophagy [183]. Meanwhile, pathogenic variants in ATL3, which belongs to the Atlastin family of proteins mediating ER morphology, also cause sensory neuropathy and increase mt-ER contacts leading to impaired axonal mitochondrial distribution [56]. Finally, it also remains to be determined whether other peripheral neuropathy genes also alter mitochondrial dynamics, and how they might impact mitochondrial function. 
Table 2. Examples of additional genes linked to peripheral neuropathy that also impair mitochondrial dynamics.

\begin{tabular}{lllc}
\hline \multicolumn{1}{c}{ Gene } & \multicolumn{1}{c}{ Protein Function } & \multicolumn{1}{c}{ Reported Mitochondrial Dysfunction } & References \\
\hline RAB7A & Vesicular transport & Reduced fission, motility and mitophagy & {$[183,359,360]$} \\
\hline ATL3 & ER network morphology & $\begin{array}{l}\text { Increased mt-ER contacts, reduced motility, sparse } \\
\text { axonal distribution }\end{array}$ & {$[56]$} \\
\hline TRPV4 & Ion channel & Defective mitochondrial motility & {$[359]$} \\
\hline SIL1 & $\begin{array}{l}\text { Co-chaperone in the ER unfolded } \\
\text { protein response }\end{array}$ & Impaired autophagy and mitochondrial maintenance & {$[361]$} \\
\hline$S A C S$ & Chaperone & Impaired mitochondrial fission & {$[362,363]$} \\
\hline NEFL & Axoskeletal component & Aberrant mitochondrial motility & {$[364]$} \\
\hline
\end{tabular}

Importantly, pathogenic variants in genes regulating mitochondrial dynamics impact a number of cellular functions in addition to mitochondrial motility that may be pertinent to peripheral neuropathy. Although we focus here on mitochondrial quality control, there are a few other examples worth briefly discussing. Mt-ER contacts, which are impacted by variants in several peripheral neuropathy proteins (e.g., MFN2, GDAP1, ATL3), are important for mediating mitochondrial function, but are also important for mitochondria fission, motility, and likely by extension quality control. On the other hand, while several mitochondrial fission proteins linked to peripheral neuropathy are also involved in mediating peroxisomal fission (e.g., DRP1, MFF, GDAP1), the fact that some pathogenic variants in DRP1 and GDAP1 do not appear to inhibit peroxisomal fission suggests that impaired peroxisomal fission is not relevant to peripheral neuropathy. Finally, while altered lipid droplets have been described in parallel with impaired mitochondrial dynamics (e.g., MFN2, DNM2), and lipid droplet impairment is also associated with peripheral neuropathy [61-63], there is not a good appreciation of whether lipid droplet alterations are upstream or downstream of mitochondrial dysfunction.

Given the limitations of reduced mitochondrial motility as a universal explanation for why the impairment of mitochondrial dynamics causes peripheral neuropathy, we highlight the likelihood that impaired mitochondrial quality control is a contributing factor. In this regard, it is also worth highlighting that mitochondrial quality control is especially important in terminally differentiated neurons that cannot be replaced. Importantly, the notion that impaired quality control plays a contributing role to peripheral neuropathy also fits with the fact that stresses causing mitochondrial damage can lead to acquired peripheral neuropathy (e.g., diabetes and cancer drugs). Additionally, it is relevant that peripheral neuropathy can be caused by pathogenic variants in mitochondrial protein chaperones such as HSPB8 (HSP22) [365], HSPB1(HSP27) [366], and TID1 [367], and that modulating chaperones can improve sensory fiber recovery in diabetic peripheral neuropathy [368]. These observations suggest that peripheral neuropathy occurs when mitochondrial damage overcomes the mitochondrial quality control mechanisms, either due to increased damage or reduced quality control. If this notion is true, a part of the explanation for why peripheral nerves are more sensitive to impaired mitochondria dysfunction could be that the quality control mechanism in peripheral nerves is not the same as for nerves in the CNS. Thus, we propose that reduced mitochondrial quality control is a consequence of impaired mitochondrial dynamics, and that insufficient mitochondrial quality control in peripheral nerves is a common thread explaining why mitochondrial dysfunction causes peripheral neuropathy.

\section{Conclusions}

In this review, we have discussed the important role that gene defects causing mitochondrial dynamic alterations have in causing peripheral neuropathy. Neuropathy is often the primary clinical feature in these disorders, and within this group of diseases there is broad clinical and neurophysiologic heterogeneity. Mitochondrial dynamic alterations 
are clearly an important etiologic category for peripheral neuropathy, particularly for monogenic disease but also in common complex disorders such as diabetic neuropathy. We have described what is currently known about the disease mechanisms and relationships between these genes. Although we do not have a full understanding of the precise mechanisms and pathogenesis, this fundamental mitochondrial function will hopefully be targetable in future therapies.

Author Contributions: Conceptualization, G.S. and T.E.S.; Writing-original draft preparation, G.S. and T.E.S.; Writing-review and editing, G.S., G.P. and T.E.S.; Visualization, G.S and T.E.S. All authors have read and agreed to the published version of the manuscript.

Funding: This research was funded by a Canadian Institutes of Health Research Project grant awarded to T.E.S.

Institutional Review Board Statement: Not applicable.

Informed Consent Statement: Not applicable.

Data Availability Statement: Not applicable.

Conflicts of Interest: The authors declare no conflict of interest.

\section{References}

1. Mandal, A.; Drerup, C.M. Axonal Transport and Mitochondrial Function in Neurons. Front. Cell. Neurosci. 2019, 13. [CrossRef]

2. Simmen, T.; Tagaya, M. Organelle Communication at Membrane Contact Sites (MCS): From Curiosity to Center Stage in Cell Biology and Biomedical Research. Adv. Exp. Med. Biol. 2017, 997, 1-12. [CrossRef] [PubMed]

3. Pickles, S.; Vigié, P.; Youle, R.J. Mitophagy and Quality Control Mechanisms in Mitochondrial Maintenance. Curr. Biol. 2018, 28, R170-R185. [CrossRef]

4. Sugiura, A.; McLelland, G.-L.; Fon, E.A.; McBride, H.M. A new pathway for mitochondrial quality control: Mitochondrial-derived vesicles. EMBO J. 2014, 33, 2142-2156. [CrossRef] [PubMed]

5. Alavi, M.V.; Bette, S.; Schimpf, S.; Schuettauf, F.; Schraermeyer, U.; Wehrl, H.F.; Ruttiger, L.; Beck, S.C.; Tonagel, F.; Pichler, B.J.; et al. A splice site mutation in the murine Opa1 gene features pathology of autosomal dominant optic atrophy. Brain 2007, 130, 1029-1042. [CrossRef] [PubMed]

6. Chen, H.; Detmer, S.A.; Ewald, A.J.; Griffin, E.E.; Fraser, S.E.; Chan, D.C. Mitofusins Mfn1 and Mfn2 coordinately regulate mitochondrial fusion and are essential for embryonic development. J. Cell Biol. 2003, 160, 189-200. [CrossRef] [PubMed]

7. Davies, V.J.; Hollins, A.J.; Piechota, M.J.; Yip, W.; Davies, J.R.; White, K.E.; Nicols, P.P.; Boulton, M.E.; Votruba, M. Opa1 deficiency in a mouse model of autosomal dominant optic atrophy impairs mitochondrial morphology, optic nerve structure and visual function. Hum. Mol. Genet. 2007, 16, 1307-1318. [CrossRef] [PubMed]

8. Ishihara, N.; Nomura, M.; Jofuku, A.; Kato, H.; Suzuki, S.O.; Masuda, K.; Otera, H.; Nakanishi, Y.; Nonaka, I.; Goto, Y.-i.; et al. Mitochondrial fission factor Drp1 is essential for embryonic development and synapse formation in mice. Nat. Cell Biol. 2009, 11, 958-966. [CrossRef] [PubMed]

9. Wakabayashi, J.; Zhang, Z.; Wakabayashi, N.; Tamura, Y.; Fukaya, M.; Kensler, T.W.; Iijima, M.; Sesaki, H. The dynamin-related GTPase Drp1 is required for embryonic and brain development in mice. J. Cell Biol. 2009, 186, 805-816. [CrossRef]

10. Chan, D.C. Mitochondrial Dynamics and Its Involvement in Disease. Annu. Rev. Pathol. Mech. Dis. 2020, 15, 235-259. [CrossRef]

11. Whitley, B.N.; Engelhart, E.A.; Hoppins, S. Mitochondrial dynamics and their potential as a therapeutic target. Mitochondrion 2019, 49, 269-283. [CrossRef]

12. Misgeld, T.; Schwarz, T.L. Mitostasis in Neurons: Maintaining Mitochondria in an Extended Cellular Architecture. Neuron 2017, 96, 651-666. [CrossRef] [PubMed]

13. Tilokani, L.; Nagashima, S.; Paupe, V.; Prudent, J. Mitochondrial dynamics: Overview of molecular mechanisms. Essays Biochem. 2018, 62, 341-360. [CrossRef] [PubMed]

14. Nunnari, J.; Suomalainen, A. Mitochondria: In Sickness and in Health. Cell 2012, 148, 1145-1159. [CrossRef] [PubMed]

15. Chen, H.; Chan, D.C. Mitochondrial dynamics-fusion, fission, movement, and mitophagy-in neurodegenerative diseases. Hum. Mol. Genet. 2009, 18, R169-R176. [CrossRef]

16. Malpartida, A.B.; Williamson, M.; Narendra, D.P.; Wade-Martins, R.; Ryan, B.J. Mitochondrial Dysfunction and Mitophagy in Parkinson's Disease: From Mechanism to Therapy. Trends Biochem. Sci. 2020. [CrossRef]

17. Alexander, C.; Votruba, M.; Pesch, U.E.A.; Thiselton, D.L.; Mayer, S.; Moore, A.; Rodriguez, M.; Kellner, U.; Leo-Kottler, B.; Auburger, G.; et al. OPA1, encoding a dynamin-related GTPase, is mutated in autosomal dominant optic atrophy linked to chromosome 3q28. Nat. Genet. 2000, 26, 211-215. [CrossRef] [PubMed]

18. Delettre, C.; Lenaers, G.; Griffoin, J.-M.; Gigarel, N.; Lorenzo, C.; Belenguer, P.; Pelloquin, L.; Grosgeorge, J.; Turc-Carel, C.; Perret, E.; et al. Nuclear gene OPA1, encoding a mitochondrial dynamin-related protein, is mutated in dominant optic atrophy. Nat. Genet. 2000, 26, 207-210. [CrossRef] [PubMed] 
19. Waterham, H.R.; Koster, J.; van Roermund, C.W.T.; Mooyer, P.A.W.; Wanders, R.J.A.; Leonard, J.V. A Lethal Defect of Mitochondrial and Peroxisomal Fission. N. Engl. J. Med. 2007, 356, 1736-1741. [CrossRef]

20. Züchner, S.; Mersiyanova, I.V.; Muglia, M.; Bissar-Tadmouri, N.; Rochelle, J.; Dadali, E.L.; Zappia, M.; Nelis, E.; Patitucci, A.; Senderek, J.; et al. Mutations in the mitochondrial GTPase mitofusin 2 cause Charcot-Marie-Tooth neuropathy type 2A. Nat. Genet. 2004, 36, 449-451. [CrossRef]

21. Nasca, A.; Scotton, C.; Zaharieva, I.; Neri, M.; Selvatici, R.; Magnusson, O.T.; Gal, A.; Weaver, D.; Rossi, R.; Armaroli, A.; et al. Recessive mutations in MSTO1 cause mitochondrial dynamics impairment, leading to myopathy and ataxia. Hum. Mutat. 2017, 38, 970-977. [CrossRef] [PubMed]

22. Gal, A.; Balicza, P.; Weaver, D.; Naghdi, S.; Joseph, S.K.; Várnai, P.; Gyuris, T.; Horváth, A.; Nagy, L.; Seifert, E.L.; et al. MSTO1 is a cytoplasmic pro-mitochondrial fusion protein, whose mutation induces myopathy and ataxia in humans. EMBO Mol. Med. 2017, 9, 967-984. [CrossRef] [PubMed]

23. Donkervoort, S.; Sabouny, R.; Yun, P.; Gauquelin, L.; Chao, K.R.; Hu, Y.; Al Khatib, I.; Töpf, A.; Mohassel, P.; Cummings, B.B.; et al. MSTO1 mutations cause mtDNA depletion, manifesting as muscular dystrophy with cerebellar involvement. Acta Neuropathol. 2019, 138, 1013-1031. [CrossRef] [PubMed]

24. Koch, J.; Feichtinger, R.G.; Freisinger, P.; Pies, M.; Schrödl, F.; Iuso, A.; Sperl, W.; Mayr, J.A.; Prokisch, H.; Haack, T.B. Disturbed mitochondrial and peroxisomal dynamics due to loss of MFF causes Leigh-like encephalopathy, optic atrophy and peripheral neuropathy. J. Med. Genet. 2016, 53, 270-278. [CrossRef]

25. Bartsakoulia, M.; Pyle, A.; Troncoso-Chandía, D.; Vial-Brizzi, J.; Paz-Fiblas, M.V.; Duff, J.; Griffin, H.; Boczonadi, V.; Lochmüller, H.; Kleinle, S.; et al. A novel mechanism causing imbalance of mitochondrial fusion and fission in human myopathies. Hum. Mol. Genet. 2018, 27, 1186-1195. [CrossRef] [PubMed]

26. Pipis, M.; Rossor, A.M.; Laura, M.; Reilly, M.M. Next-generation sequencing in Charcot-Marie-Tooth disease: Opportunities and challenges. Nat. Rev. Neurol. 2019, 15, 644-656. [CrossRef]

27. Liu, X.; Duan, X.; Zhang, Y.; Sun, A.; Fan, D. Molecular analysis and clinical diversity of distal hereditary motor neuropathy. Eur. J. Neurol. 2020, 27, 1319-1326. [CrossRef] [PubMed]

28. Schwartzlow, C.; Kazamel, M. Hereditary sensory and autonomic neuropathies: Adding more to the classification. Curr. Neurol. Neurosci. Rep. 2019, 19, 1-11. [CrossRef]

29. Bombelli, F.; Stojkovic, T.; Dubourg, O.; Echaniz-Laguna, A.; Tardieu, S.; Larcher, K.; Amati-Bonneau, P.; Latour, P.; Vignal, O.; Cazeneuve, C. Charcot-Marie-Tooth disease type 2A: From typical to rare phenotypic and genotypic features. JAMA Neurol. 2014, 71, 1036-1042. [CrossRef]

30. Zhu, D.; Kennerson, M.L.; Walizada, G.; Züchner, S.; Vance, J.M.; Nicholson, G.A. Charcot-Marie-Tooth with pyramidal signs is genetically heterogeneous: Families with and without MFN2 mutations. Neurology 2005, 65, 496-497. [CrossRef] [PubMed]

31. Klein, C.J.; Duan, X.; Shy, M.E. Inherited neuropathies: Clinical overview and update. Muscle Nerve 2013, 48, 604-622. [CrossRef] [PubMed]

32. Laurá, M.; Pipis, M.; Rossor, A.M.; Reilly, M.M. Charcot-Marie-Tooth disease and related disorders: An evolving landscape. Curr. Opin. Neurol. 2019, 32, 641-650. [CrossRef]

33. Karol, L.A.; Elerson, E. Scoliosis in patients with Charcot-Marie-Tooth disease. JBJS 2007, 89, 1504-1510. [CrossRef]

34. Laurá, M.; Singh, D.; Ramdharry, G.; Morrow, J.; Skorupinska, M.; Pareyson, D.; Burns, J.; Lewis, R.A.; Scherer, S.S.; Herrmann, D.N. Prevalence and orthopedic management of foot and ankle deformities in Charcot-Marie-Tooth disease. Muscle Nerve 2018, 57, 255-259. [CrossRef]

35. Spiesshoefer, J.; Henke, C.; Kabitz, H.J.; Akova-Oeztuerk, E.; Draeger, B.; Herkenrath, S.; Randerath, W.; Young, P.; Brix, T.; Boentert, M. Phrenic nerve involvement and respiratory muscle weakness in patients with Charcot-Marie-Tooth disease 1A. J. Peripher. Nerv. Syst. 2019, 24, 283-293. [CrossRef]

36. Aboussouan, L.S.; Lewis, R.A.; Shy, M.E. Disorders of pulmonary function, sleep, and the upper airway in Charcot-Marie-Tooth disease. Lung 2007, 185, 1-7. [CrossRef]

37. Magy, L.; Mathis, S.; Le Masson, G.; Goizet, C.; Tazir, M.; Vallat, J.-M. Updating the classification of inherited neuropathies: Results of an international survey. Neurology 2018, 90, e870-e876. [CrossRef]

38. Berciano, J.; García, A.; Gallardo, E.; Peeters, K.; Pelayo-Negro, A.L.; Alvarez-Paradelo, S.; Gazulla, J.; Martínez-Tames, M.; Infante, J.; Jordanova, A. Intermediate Charcot-Marie-Tooth disease: An electrophysiological reappraisal and systematic review. J. Neurol. 2017, 264, 1655-1677. [CrossRef]

39. Skre, H. Genetic and clinical aspects of Charcot-Marie-Tooth's disease. Clin. Genet. 1974, 6, 98-118. [CrossRef]

40. Fridman, V.; Bundy, B.; Reilly, M.M.; Pareyson, D.; Bacon, C.; Burns, J.; Day, J.; Feely, S.; Finkel, R.S.; Grider, T. CMT subtypes and disease burden in patients enrolled in the Inherited Neuropathies Consortium natural history study: A cross-sectional analysis. J. Neurol. Neurosurg. Psychiatry 2015, 86, 873-878. [CrossRef] [PubMed]

41. Rossor, A.M.; Carr, A.S.; Devine, H.; Chandrashekar, H.; Pelayo-Negro, A.L.; Pareyson, D.; Shy, M.E.; Scherer, S.S.; Reilly, M.M. Peripheral neuropathy in complex inherited diseases: An approach to diagnosis. J. Neurol. Neurosurg. Psychiatry 2017, 88, 846-863. [CrossRef]

42. Pfeffer, G.; Chinnery, P.F. Diagnosis and treatment of mitochondrial myopathies. Ann. Med. 2013, 45, 4-16. [CrossRef]

43. Pareyson, D.; Piscosquito, G.; Moroni, I.; Salsano, E.; Zeviani, M. Peripheral neuropathy in mitochondrial disorders. Lancet Neurol. 2013, 12, 1011-1024. [CrossRef] 
44. Pfeffer, G.; Sirrs, S.; Wade, N.K.; Mezei, M.M. Multisystem disorder in late-onset chronic progressive external ophthalmoplegia. Can. J. Neurol. Sci. 2011, 38, 119-123. [CrossRef] [PubMed]

45. Lu, J.-Q.; Tarnopolsky, M.A. Mitochondrial neuropathy and neurogenic features in mitochondrial myopathy. Mitochondrion 2021, 56, 52-61. [CrossRef]

46. Schmidt, R.E. Chapter One-Mitochondriopathy: The unifying concept in distal neuropathies? In International Review of Neurobiology; Fernyhough, P., Calcutt, N.A., Eds.; Academic Press: Amsterdam, The Netherlands, 2019; Volume 145, pp. 1-12.

47. Sifuentes-Franco, S.; Pacheco-Moisés, F.P.; Rodríguez-Carrizalez, A.D.; Miranda-Díaz, A.G. The Role of Oxidative Stress, Mitochondrial Function, and Autophagy in Diabetic Polyneuropathy. J. Diabetes Res. 2017, 2017, 1673081. [CrossRef]

48. Trecarichi, A.; Flatters, S.J.L. Chapter Five-Mitochondrial dysfunction in the pathogenesis of chemotherapy-induced peripheral neuropathy. In International Review of Neurobiology; Fernyhough, P., Calcutt, N.A., Eds.; Academic Press: Amsterdam, The Netherlands, 2019; Volume 145, pp. 83-126.

49. Staff, N.P.; Fehrenbacher, J.C.; Caillaud, M.; Damaj, M.I.; Segal, R.A.; Rieger, S. Pathogenesis of paclitaxel-induced peripheral neuropathy: A current review of in vitro and in vivo findings using rodent and human model systems. Exp. Neurol. 2020, 324, 113121. [CrossRef] [PubMed]

50. Calls, A.; Carozzi, V.; Navarro, X.; Monza, L.; Bruna, J. Pathogenesis of platinum-induced peripheral neurotoxicity: Insights from preclinical studies. Exp. Neurol. 2020, 325, 113141. [CrossRef] [PubMed]

51. Rumora, A.E.; Savelieff, M.G.; Sakowski, S.A.; Feldman, E.L. Chapter Six-Disorders of mitochondrial dynamics in peripheral neuropathy: Clues from hereditary neuropathy and diabetes. In International Review of Neurobiology; Fernyhough, P., Calcutt, N.A., Eds.; Academic Press: Amsterdam, The Netherlands, 2019; Volume 145, pp. 27-176.

52. Farmer, T.; Naslavsky, N.; Caplan, S. Tying trafficking to fusion and fission at the mighty mitochondria. Traffic 2018, 19, 569-577. [CrossRef]

53. Pareyson, D.; Saveri, P.; Sagnelli, A.; Piscosquito, G. Mitochondrial dynamics and inherited peripheral nerve diseases. Neurosci. Lett. 2015, 596, 66-77. [CrossRef]

54. Zaninello, M.; Palikaras, K.; Naon, D.; Iwata, K.; Herkenne, S.; Quintana-Cabrera, R.; Semenzato, M.; Grespi, F.; Ross-Cisneros, F.N.; Carelli, V.; et al. Inhibition of autophagy curtails visual loss in a model of autosomal dominant optic atrophy. Nat. Commun. 2020, 11, 4029. [CrossRef]

55. Gregianin, E.; Pallafacchina, G.; Zanin, S.; Crippa, V.; Rusmini, P.; Poletti, A.; Fang, M.; Li, Z.; Diano, L.; Petrucci, A.; et al. Loss-of-function mutations in the SIGMAR1 gene cause distal hereditary motor neuropathy by impairing ER-mitochondria tethering and Ca2+ signalling. Hum. Mol. Genet. 2016, 25, 3741-3753. [CrossRef]

56. Krols, M.; Asselbergh, B.; De Rycke, R.; De Winter, V.; Seyer, A.; Müller, F.-J.; Kurth, I.; Bultynck, G.; Timmerman, V.; Janssens, S. Sensory neuropathy-causing mutations in ATL3 affect ER-mitochondria contact sites and impair axonal mitochondrial distribution. Hum. Mol. Genet. 2018, 28, 615-627. [CrossRef]

57. Larrea, D.; Pera, M.; Gonnelli, A.; Quintana-Cabrera, R.; Akman, H.O.; Guardia-Laguarta, C.; Velasco, K.R.; Area-Gomez, E.; Dal Bello, F.; De Stefani, D.; et al. MFN2 mutations in Charcot-Marie-Tooth disease alter mitochondria-associated ER membrane function but do not impair bioenergetics. Hum. Mol. Genet. 2019, 28, 1782-1800. [CrossRef] [PubMed]

58. Bernard-Marissal, N.; van Hameren, G.; Juneja, M.; Pellegrino, C.; Louhivuori, L.; Bartesaghi, L.; Rochat, C.; El Mansour, O.; Médard, J.-J.; Croisier, M.; et al. Altered interplay between endoplasmic reticulum and mitochondria in Charcot-Marie-Tooth type 2A neuropathy. Proc. Natl. Acad. Sci. USA 2019, 116, 2328-2337. [CrossRef] [PubMed]

59. Suresh, S.N. Endoplasmic reticulum mitochondria contacts modulate apoptosis of renal cells and its implications in diabetic neuropathy. EBioMedicine 2019, 44, 24-25. [CrossRef] [PubMed]

60. Benador, I.Y.; Veliova, M.; Liesa, M.; Shirihai, O.S. Mitochondria Bound to Lipid Droplets: Where Mitochondrial Dynamics Regulate Lipid Storage and Utilization. Cell Metab. 2019, 29, 827-835. [CrossRef] [PubMed]

61. Tinelli, E.; Pereira, J.A.; Suter, U. Muscle-specific function of the centronuclear myopathy and Charcot-Marie-Tooth neuropathyassociated dynamin 2 is required for proper lipid metabolism, mitochondria, muscle fibers, neuromuscular junctions and peripheral nerves. Hum. Mol. Genet. 2013, 22, 4417-4429. [CrossRef]

62. Marshall, L.L.; Stimpson, S.E.; Hyland, R.; Coorssen, J.R.; Myers, S.J. Increased lipid droplet accumulation associated with a peripheral sensory neuropathy. J. Chem. Biol. 2014, 7, 67-76. [CrossRef] [PubMed]

63. Giudetti, A.M.; Guerra, F.; Longo, S.; Beli, R.; Romano, R.; Manganelli, F.; Nolano, M.; Mangini, V.; Santoro, L.; Bucci, C. An altered lipid metabolism characterizes Charcot-Marie-Tooth type 2B peripheral neuropathy. Biochim. Biophys. Acta (BBA) Mol. Cell Biol. Lipids 2020, 1865, 158805. [CrossRef]

64. Mattie, S.; Krols, M.; McBride, H.M. The enigma of an interconnected mitochondrial reticulum: New insights into mitochondrial fusion. Curr. Opin. Cell Biol. 2019, 59, 159-166. [CrossRef] [PubMed]

65. Hoppins, S.; Edlich, F.; Cleland, M.M.; Banerjee, S.; McCaffery, J.M.; Youle, R.J.; Nunnari, J. The Soluble Form of Bax Regulates Mitochondrial Fusion via MFN2 Homotypic Complexes. Mol. Cell 2011, 41, 150-160. [CrossRef]

66. Olichon, A.; Emorine, L.J.; Descoins, E.; Pelloquin, L.; Brichese, L.; Gas, N.; Guillou, E.; Delettre, C.; Valette, A.; Hamel, C.P. The human dynamin-related protein OPA1 is anchored to the mitochondrial inner membrane facing the inter-membrane space. FEBS Lett. 2002, 523, 171-176. [CrossRef]

67. Song, Z.; Ghochani, M.; McCaffery, J.M.; Frey, T.G.; Chan, D.C. Mitofusins and OPA1 mediate sequential steps in mitochondrial membrane fusion. Mol. Biol. Cell 2009, 20, 3525-3532. [CrossRef] 
68. Liu, R.; Chan, D.C. OPA1 and cardiolipin team up for mitochondrial fusion. Nat. Cell. Biol. 2017, 19, 760-762. [CrossRef]

69. Ban, T.; Ishihara, T.; Kohno, H.; Saita, S.; Ichimura, A.; Maenaka, K. Molecular basis of selective mitochondrial fusion by heterotypic action between OPA1 and cardiolipin. Nat. Cell. Biol. 2017, 19, 856-863. [CrossRef]

70. Huang, H.; Gao, Q.; Peng, X.; Choi, S.-Y.; Sarma, K.; Ren, H.; Morris, A.J.; Frohman, M.A. piRNA-Associated Germline Nuage Formation and Spermatogenesis Require MitoPLD Profusogenic Mitochondrial-Surface Lipid Signaling. Dev. Cell 2011, 20, 376-387. [CrossRef]

71. Zhang, Y.; Liu, X.; Bai, J.; Tian, X.; Zhao, X.; Liu, W.; Duan, X.; Shang, W.; Fan, H.-Y.; Tong, C. Mitoguardin Regulates Mitochondrial Fusion through MitoPLD and Is Required for Neuronal Homeostasis. Mol. Cell 2016, 61, 111-124. [CrossRef] [PubMed]

72. Schiavon, C.R.; Turn, R.E.; Newman, L.E.; Kahn, R.A. ELMOD2 regulates mitochondrial fusion in a mitofusin-dependent manner, downstream of ARL2. Mol. Biol. Cell 2019, 30, 1198-1213. [CrossRef] [PubMed]

73. Newman, L.E.; Schiavon, C.R.; Turn, R.E.; Kahn, R.A. The ARL2 GTPase regulates mitochondrial fusion from the intermembrane space. Cell. Logist. 2017, 7, e1340104. [CrossRef]

74. Janer, A.; Prudent, J.; Paupe, V.; Fahiminiya, S.; Majewski, J.; Sgarioto, N.; Des Rosiers, C.; Forest, A.; Lin, Z.-Y.; Gingras, A.-C.; et al. SLC25A46 is required for mitochondrial lipid homeostasis and cristae maintenance and is responsible for Leigh syndrome. EMBO Mol. Med. 2016, 8, 1019-1038. [CrossRef] [PubMed]

75. Steffen, J.; Vashisht, A.A.; Wan, J.; Jen, J.C.; Claypool, S.M.; Wohlschlegel, J.A.; Koehler, C.M. Rapid degradation of mutant SLC25A46 by the ubiquitin-proteasome system results in MFN1/2-mediated hyperfusion of mitochondria. Mol. Biol. Cell 2017, 28, 600-612. [CrossRef] [PubMed]

76. Jiao, Y.; Kuang, S.; Yang, S.; Han, X. Evidence of motor axon or motor neuron damage in a Chinese patient with compound heterozygous MSTO1 variants. Acta Neurol. Belg. 2020. [CrossRef]

77. Qi, Y.; Yan, L.; Yu, C.; Guo, X.; Zhou, X.; Hu, X.; Huang, X.; Rao, Z.; Lou, Z.; Hu, J. Structures of human mitofusin 1 provide insight into mitochondrial tethering. J. Cell Biol. 2016, 215, 621-629. [CrossRef]

78. Cao, Y.-L.; Meng, S.; Chen, Y.; Feng, J.-X.; Gu, D.-D.; Yu, B.; Li, Y.-J.; Yang, J.-Y.; Liao, S.; Chan, D.C.; et al. MFN1 structures reveal nucleotide-triggered dimerization critical for mitochondrial fusion. Nature 2017, 542, 372-376. [CrossRef]

79. Yan, L.; Qi, Y.; Huang, X.; Yu, C.; Lan, L.; Guo, X.; Rao, Z.; Hu, J.; Lou, Z. Structural basis for GTP hydrolysis and conformational change of MFN1 in mediating membrane fusion. Nat. Struct. Mol. Biol. 2018, 25, 233-243. [CrossRef] [PubMed]

80. Li, Y.-J.; Cao, Y.-L.; Feng, J.-X.; Qi, Y.; Meng, S.; Yang, J.-F.; Zhong, Y.-T.; Kang, S.; Chen, X.; Lan, L.; et al. Structural insights of human mitofusin-2 into mitochondrial fusion and CMT2A onset. Nat. Commun. 2019, 10, 4914. [CrossRef]

81. De Brito, O.M.; Scorrano, L. Mitofusin 2 tethers endoplasmic reticulum to mitochondria. Nature 2008, 456, 605. [CrossRef] [PubMed]

82. Filadi, R.; Greotti, E.; Turacchio, G.; Luini, A.; Pozzan, T.; Pizzo, P. Mitofusin 2 ablation increases endoplasmic reticulummitochondria coupling. Proc. Natl. Acad. Sci. USA 2015, 112, E2174-E2181. [CrossRef]

83. Filadi, R.; Greotti, E.; Turacchio, G.; Luini, A.; Pozzan, T.; Pizzo, P. On the role of Mitofusin 2 in endoplasmic reticulummitochondria tethering. Proc. Natl. Acad. Sci. USA 2017, 114, E2266-E2267. [CrossRef]

84. Naon, D.; Zaninello, M.; Giacomello, M.; Varanita, T.; Grespi, F.; Lakshminaranayan, S.; Serafini, A.; Semenzato, M.; Herkenne, S.; Hernández-Alvarez, M.I.; et al. Critical reappraisal confirms that Mitofusin 2 is an endoplasmic reticulum-mitochondria tether. Proc. Natl. Acad. Sci. USA 2016, 113, 11249-11254. [CrossRef] [PubMed]

85. Naon, D.; Zaninello, M.; Giacomello, M.; Varanita, T.; Grespi, F.; Lakshminaranayan, S.; Serafini, A.; Semenzato, M.; Herkenne, S.; Hernández-Alvarez, M.I.; et al. Reply to Filadi et al.: Does Mitofusin 2 tether or separate endoplasmic reticulum and mitochondria? Proc. Natl. Acad. Sci. USA 2017, 114, E2268-E2269. [CrossRef] [PubMed]

86. Pham, A.H.; Meng, S.; Chu, Q.N.; Chan, D.C. Loss of Mfn2 results in progressive, retrograde degeneration of dopaminergic neurons in the nigrostriatal circuit. Hum. Mol. Genet. 2012, 21, 4817-4826. [CrossRef]

87. Misko, A.; Jiang, S.; Wegorzewska, I.; Milbrandt, J.; Baloh, R.H. Mitofusin 2 Is Necessary for Transport of Axonal Mitochondria and Interacts with the Miro/Milton Complex. J. Neurosci. 2010, 30, 4232-4240. [CrossRef] [PubMed]

88. Chan, N.C.; Salazar, A.M.; Pham, A.H.; Sweredoski, M.J.; Kolawa, N.J.; Graham, R.L.J.; Hess, S.; Chan, D.C. Broad activation of the ubiquitin-proteasome system by Parkin is critical for mitophagy. Hum. Mol. Genet. 2011, 20, 1726-1737. [CrossRef] [PubMed]

89. Gegg, M.E.; Cooper, J.M.; Chau, K.-Y.; Rojo, M.; Schapira, A.H.V.; Taanman, J.-W. Mitofusin 1 and mitofusin 2 are ubiquitinated in a PINK1/parkin-dependent manner upon induction of mitophagy. Hum. Mol. Genet. 2010, 19, 4861-4870. [CrossRef] [PubMed]

90. Rakovic, A.; Grünewald, A.; Kottwitz, J.; Brüggemann, N.; Pramstaller, P.P.; Lohmann, K.; Klein, C. Mutations in PINK1 and Parkin impair ubiquitination of Mitofusins in human fibroblasts. PLoS ONE 2011, 6, e16746. [CrossRef]

91. Chen, Y.; Dorn, G.W. PINK1-Phosphorylated Mitofusin 2 Is a Parkin Receptor for Culling Damaged Mitochondria. Science 2013, 340, 471-475. [CrossRef]

92. Bradbury, J. Mitochondrial fusion protein mutated in CMT2A. Lancet Neurol. 2004, 3, 326. [CrossRef]

93. Stuppia, G.; Rizzo, F.; Riboldi, G.; Del Bo, R.; Nizzardo, M.; Simone, C.; Comi, G.P.; Bresolin, N.; Corti, S. MFN2-related neuropathies: Clinical features, molecular pathogenesis and therapeutic perspectives. J. Neurol. Sci. 2015, 356, 7-18. [CrossRef] [PubMed]

94. Tufano, M.; Cappuccio, G.; Terrone, G.; Manganelli, F.; Pisciotta, C.; Geroldi, A.; Capponi, S.; Del Giudice, E. Early onset Charcot-Marie-Tooth neuropathy type 2A and severe developmental delay: Expanding the clinical phenotype of MFN2-related neuropathy. J. Peripher. Nerv. Syst. 2015, 20, 415-418. [CrossRef] [PubMed] 
95. Nightingale, H.; Pfeffer, G.; Horvath, R. Chronic and slowly progressive weakness of the legs and hands. BMJ Br. Med. J. 2014, 348, g459. [CrossRef] [PubMed]

96. Nicholson, G.A.; Magdelaine, C.; Zhu, D.; Grew, S.; Ryan, M.M.; Sturtz, F.; Vallat, J.-M.; Ouvrier, R.A. Severe early-onset axonal neuropathy with homozygous and compound heterozygous MFN2 mutations. Neurology 2008, 70, 1678-1681. [CrossRef] [PubMed]

97. Rouzier, C.; Bannwarth, S.; Chaussenot, A.; Chevrollier, A.; Verschueren, A.; Bonello-Palot, N.; Fragaki, K.; Cano, A.; Pouget, J.; Pellissier, J.-F.; et al. The MFN2 gene is responsible for mitochondrial DNA instability and optic atrophy 'plus' phenotype. Brain 2011, 135, 23-34. [CrossRef]

98. Chung, K.W.; Kim, S.B.; Park, K.D.; Choi, K.G.; Lee, J.H.; Eun, H.W.; Suh, J.S.; Hwang, J.H.; Kim, W.K.; Seo, B.C.; et al. Early onset severe and late-onset mild Charcot-Marie-Tooth disease with mitofusin 2 (MFN2) mutations. Brain 2006, 129, $2103-2118$. [CrossRef]

99. Capel, E.; Vatier, C.; Cervera, P.; Stojkovic, T.; Disse, E.; Cottereau, A.-S.; Auclair, M.; Verpont, M.-C.; Mosbah, H.; Gourdy, P.; et al. MFN2-associated lipomatosis: Clinical spectrum and impact on adipose tissue. J. Clin. Lipidol. 2018, 12, 1420-1435. [CrossRef]

100. Rocha, N.; Bulger, D.A.; Frontini, A.; Titheradge, H.; Gribsholt, S.B.; Knox, R.; Page, M.; Harris, J.; Payne, F.; Adams, C.; et al. Human biallelic MFN2 mutations induce mitochondrial dysfunction, upper body adipose hyperplasia, and suppression of leptin expression. eLife 2017, 6, e23813. [CrossRef] [PubMed]

101. Sawyer, S.L.; Cheuk-Him Ng, A.; Innes, A.M.; Wagner, J.D.; Dyment, D.A.; Tetreault, M.; Consortium, C.R.C.; Majewski, J.; Boycott, K.M.; Screaton, R.A.; et al. Homozygous mutations in MFN2 cause multiple symmetric lipomatosis associated with neuropathy. Hum. Mol. Genet. 2015, 24, 5109-5114. [CrossRef]

102. Sharma, G.; Sabouny, R.; Joel, M.; Martens, K.; de Koning, J.; Martino, D.; Pfeffer, G.; Shutt, T.E. Characterization of a novel variant in the HR1 domain of MFN2 in a patient with ataxia, optic atrophy and sensorineural hearing loss. bioRxiv 2021. [CrossRef]

103. Amiott, E.A.; Lott, P.; Soto, J.; Kang, P.B.; McCaffery, J.M.; DiMauro, S.; Abel, E.D.; Flanigan, K.M.; Lawson, V.H.; Shaw, J.M. Mitochondrial fusion and function in Charcot-Marie-Tooth type 2A patient fibroblasts with mitofusin 2 mutations. Exp. Neurol. 2008, 211, 115-127. [CrossRef]

104. Loiseau, D.; Chevrollier, A.; Verny, C.; Guillet, V.; Gueguen, N.; Pou De Crescenzo, M.-A.; Ferré, M.; Malinge, M.-C.; Guichet, A.; Nicolas, G.; et al. Mitochondrial coupling defect in Charcot-Marie-Tooth type 2A disease. Ann. Neurol. 2007, 61, 315-323. [CrossRef] [PubMed]

105. El Fissi, N.; Rojo, M.; Aouane, A.; Karatas, E.; Poliacikova, G.; David, C.; Royet, J.; Rival, T. Mitofusin gain and loss of function drive pathogenesis in Drosophila models of CMT2A neuropathy. EMBO Rep. 2018, 19, e45241. [CrossRef] [PubMed]

106. Codron, P.; Chevrollier, A.; Kane, M.S.; Echaniz-Laguna, A.; Latour, P.; Reynier, P.; Bonneau, D.; Verny, C.; Procaccio, V.; Lenaers, G.; et al. Increased mitochondrial fusion in a autosomal recessive CMT2A family with mitochondrial GTPase mitofusin 2 mutations. J. Peripher. Nerv. Syst. 2016, 21, 365-369. [CrossRef] [PubMed]

107. Sitarz, K.S.; Yu-Wai-Man, P.; Pyle, A.; Stewart, J.D.; Rautenstrauss, B.; Seeman, P.; Reilly, M.M.; Horvath, R.; Chinnery, P.F. MFN2 mutations cause compensatory mitochondrial DNA proliferation. Brain 2012, 135, e219. [CrossRef]

108. Vielhaber, S.; Debska-Vielhaber, G.; Peeva, V.; Schoeler, S.; Kudin, A.P.; Minin, I.; Schreiber, S.; Dengler, R.; Kollewe, K.; Zuschratter, W. Mitofusin 2 mutations affect mitochondrial function by mitochondrial DNA depletion. Acta Neuropathol. 2013, 125, 245-256. [CrossRef] [PubMed]

109. Strickland, A.V.; Rebelo, A.P.; Zhang, F.; Price, J.; Bolon, B.; Silva, J.P.; Wen, R.; Züchner, S. Characterization of the mitofusin 2 R94W mutation in a knock-in mouse model. J. Peripher. Nerv. Syst. 2014, 19, 152-164. [CrossRef] [PubMed]

110. Baloh, R.H.; Schmidt, R.E.; Pestronk, A.; Milbrandt, J. Altered axonal mitochondrial transport in the pathogenesis of CharcotMarie-Tooth disease from mitofusin 2 mutations. J. Neurosci. 2007, 27, 422-430. [CrossRef] [PubMed]

111. Dorn, G.W. Mitofusin 2 Dysfunction and Disease in Mice and Men. Front. Physiol. 2020, 11. [CrossRef] [PubMed]

112. Franco, A.; Dang, X.; Walton, E.K.; Ho, J.N.; Zablocka, B.; Ly, C.; Miller, T.M.; Baloh, R.H.; Shy, M.E.; Yoo, A.S.; et al. Burst mitofusin activation reverses neuromuscular dysfunction in murine CMT2A. eLife 2020, 9, e61119. [CrossRef] [PubMed]

113. Rocha, A.G.; Franco, A.; Krezel, A.M.; Rumsey, J.M.; Alberti, J.M.; Knight, W.C.; Biris, N.; Zacharioudakis, E.; Janetka, J.W.; Baloh, R.H. MFN2 agonists reverse mitochondrial defects in preclinical models of Charcot-Marie-Tooth disease type 2A. Science 2018, 360, 336-341. [CrossRef] [PubMed]

114. MacVicar, T.; Langer, T. OPA1 processing in cell death and disease-the long and short of it. J. Cell Sci. 2016, 129, 2297-2306. [CrossRef] [PubMed]

115. Anand, R.; Wai, T.; Baker, M.J.; Kladt, N.; Schauss, A.C.; Rugarli, E.; Langer, T. The i-AAA protease YME1L and OMA1 cleave OPA1 to balance mitochondrial fusion and fission. J. Cell. Biol. 2014, 204, 919-929. [CrossRef] [PubMed]

116. Ishihara, N.; Fujita, Y.; Oka, T.; Mihara, K. Regulation of mitochondrial morphology through proteolytic cleavage of OPA1. EMBO J. 2006, 25, 2966-2977. [CrossRef] [PubMed]

117. Wang, R.; Mishra, P.; Garbis, S.D.; Moradian, A.; Sweredoski, M.J.; Chan, D.C. Identification of new OPA1 cleavage site reveals that short isoforms regulate mitochondrial fusion. Mol. Biol. Cell 2020, mbcE20090605. [CrossRef]

118. Del Dotto, V.; Mishra, P.; Vidoni, S.; Fogazza, M.; Maresca, A.; Caporali, L.; McCaffery, J.M.; Cappelletti, M.; Baruffini, E.; Lenaers, G.; et al. OPA1 Isoforms in the Hierarchical Organization of Mitochondrial Functions. Cell Rep. 2017, 19, $2557-2571$. [CrossRef] [PubMed] 
119. Yang, L.; Tang, H.; Lin, X.; Wu, Y.; Zeng, S.; Pan, Y.; Li, Y.; Xiang, G.; Lin, Y.-F.; Zhuang, S.-M.; et al. OPA1-Exon4b Binds to mtDNA D-Loop for Transcriptional and Metabolic Modulation, Independent of Mitochondrial Fusion. Front. Cell Dev. Biol. 2020, 8. [CrossRef] [PubMed]

120. Elachouri, G.; Vidoni, S.; Zanna, C.; Pattyn, A.; Boukhaddaoui, H.; Gaget, K.; Yu-Wai-Man, P.; Gasparre, G.; Sarzi, E.; Delettre, C.; et al. OPA1 links human mitochondrial genome maintenance to mtDNA replication and distribution. Genome Res. 2011, 21, 12-20. [CrossRef]

121. Faelber, K.; Dietrich, L.; Noel, J.K.; Wollweber, F.; Pfitzner, A.-K.; Mühleip, A.; Sánchez, R.; Kudryashev, M.; Chiaruttini, N.; Lilie, H.; et al. Structure and assembly of the mitochondrial membrane remodelling GTPase Mgm1. Nature 2019, 571, 429-433. [CrossRef] [PubMed]

122. Yan, L.; Qi, Y.; Ricketson, D.; Li, L.; Subramanian, K.; Zhao, J.; Yu, C.; Wu, L.; Sarsam, R.; Wong, M.; et al. Structural analysis of a trimeric assembly of the mitochondrial dynamin-like GTPase Mgm1. Proc. Natl. Acad. Sci. USA 2020, 117, 4061-4070. [CrossRef] [PubMed]

123. Cohn, A.C.; Toomes, C.; Potter, C.; Towns, K.V.; Hewitt, A.W.; Inglehearn, C.F.; Craig, J.E.; Mackey, D.A. Autosomal Dominant Optic Atrophy: Penetrance and Expressivity in Patients With OPA1 Mutations. Am. J. Ophthalmol. 2007, 143, 656-662.e651. [CrossRef]

124. Ferré, M.; Bonneau, D.; Milea, D.; Chevrollier, A.; Verny, C.; Dollfus, H.; Ayuso, C.; Defoort, S.; Vignal, C.; Zanlonghi, X.; et al. Molecular screening of 980 cases of suspected hereditary optic neuropathy with a report on 77 novel OPA1 mutations. Hum. Mutat. 2009, 30, E692-E705. [CrossRef]

125. Amati-Bonneau, P.; Guichet, A.; Olichon, A.; Chevrollier, A.; Viala, F.; Miot, S.; Ayuso, C.; Odent, S.; Arrouet, C.; Verny, C.; et al. OPA1 R445H mutation in optic atrophy associated with sensorineural deafness. Ann. Neurol. 2005, 58, 958-963. [CrossRef] [PubMed]

126. Maeda-Katahira, A.; Nakamura, N.; Hayashi, T.; Katagiri, S.; Shimizu, S.; Ohde, H.; Matsunaga, T.; Kaga, K.; Nakano, T.; Kameya, S.; et al. Autosomal dominant optic atrophy with OPA1 gene mutations accompanied by auditory neuropathy and other systemic complications in a Japanese cohort. Mol. Vis. 2019, 25, 559-573.

127. Yu-Wai-Man, P.; Griffiths, P.G.; Gorman, G.S.; Lourenco, C.M.; Wright, A.F.; Auer-Grumbach, M.; Toscano, A.; Musumeci, O.; Valentino, M.L.; Caporali, L.; et al. Multi-system neurological disease is common in patients with OPA1 mutations. Brain A J. Neurol. 2010, 133, 771-786. [CrossRef]

128. Yu-Wai-Man, C.; Smith, F.E.; Firbank, M.J.; Guthrie, G.; Guthrie, S.; Gorman, G.S.; Taylor, R.W.; Turnbull, D.M.; Griffiths, P.G.; Blamire, A.M. Extraocular muscle atrophy and central nervous system involvement in chronic progressive external ophthalmoplegia. PLoS ONE 2013, 8, e75048. [CrossRef] [PubMed]

129. Bonneau, D.; Colin, E.; Oca, F.; Ferré, M.; Chevrollier, A.; Guéguen, N.; Desquiret-Dumas, V.; N'Guyen, S.; Barth, M.; Zanlonghi, X.; et al. Early-onset Behr syndrome due to compound heterozygous mutations in OPA1. Brain 2014, 137, e301. [CrossRef] [PubMed]

130. Carelli, V.; Sabatelli, M.; Carrozzo, R.; Rizza, T.; Schimpf, S.; Wissinger, B.; Zanna, C.; Rugolo, M.; La Morgia, C.; Caporali, L.; et al. 'Behr syndrome' with OPA1 compound heterozygote mutations. Brain 2014, 138, e321. [CrossRef] [PubMed]

131. Kane, M.S.; Alban, J.; Desquiret-Dumas, V.; Gueguen, N.; Ishak, L.; Ferre, M.; Amati-Bonneau, P.; Procaccio, V.; Bonneau, D.; Lenaers, G.; et al. Autophagy controls the pathogenicity of OPA1 mutations in dominant optic atrophy. J. Cell. Mol. Med. 2017, 21, 2284-2297. [CrossRef]

132. Nasca, A.; Rizza, T.; Doimo, M.; Legati, A.; Ciolfi, A.; Diodato, D.; Calderan, C.; Carrara, G.; Lamantea, E.; Aiello, C.; et al. Not only dominant, not only optic atrophy: Expanding the clinical spectrum associated with OPA1 mutations. Orphanet J. Rare Dis. 2017, 12, 89. [CrossRef]

133. Lee, J.; Jung, S.C.; Hong, Y.B.; Yoo, J.H.; Koo, H.; Lee, J.H.; Hong, H.D.; Kim, S.B.; Chung, K.W.; Choi, B.O. Recessive optic atrophy, sensorimotor neuropathy and cataract associated with novel compound heterozygous mutations in OPA1. Mol. Med. Rep. 2016, 14, 33-40. [CrossRef]

134. Spiegel, R.; Saada, A.; Flannery, P.J.; Burté, F.; Soiferman, D.; Khayat, M.; Eisner, V.; Vladovski, E.; Taylor, R.W.; Bindoff, L.A. Fatal infantile mitochondrial encephalomyopathy, hypertrophic cardiomyopathy and optic atrophy associated with a homozygous OPA1 mutation. J. Med. Genet. 2016, 53, 127-131. [CrossRef] [PubMed]

135. Marelli, C.; Amati-Bonneau, P.; Reynier, P.; Layet, V.; Layet, A.; Stevanin, G.; Brissaud, E.; Bonneau, D.; Durr, A.; Brice, A. Heterozygous OPA1 mutations in Behr syndrome. Brain 2011, 134, e169. [CrossRef] [PubMed]

136. Rubegni, A.; Pisano, T.; Bacci, G.; Tessa, A.; Battini, R.; Procopio, E.; Giglio, S.; Pasquariello, R.; Santorelli, F.M.; Guerrini, R. Leigh-like neuroimaging features associated with new biallelic mutations in OPA1. Eur. J. Paediatr. Neurol. $2017,21,671-677$. [CrossRef] [PubMed]

137. Kamei, S.; Chen-Kuo-Chang, M.; Cazevieille, C.; Lenaers, G.; Olichon, A.l.; Belenguer, P.; Roussignol, G.; Renard, N.; Eybalin, M.; Michelin, A.; et al. Expression of the Opa1 Mitochondrial Protein in Retinal Ganglion Cells: Its Downregulation Causes Aggregation of the Mitochondrial Network. Investig. Ophthalmol. Vis. Sci. 2005, 46, 4288-4294. [CrossRef] [PubMed]

138. Bertholet, A.M.; Millet, A.M.E.; Guillermin, O.; Daloyau, M.; Davezac, N.; Miquel, M.-C.; Belenguer, P. OPA1 loss of function affects in vitro neuronal maturation. Brain 2013, 136, 1518-1533. [CrossRef] [PubMed] 
139. Moulis, M.F.; Millet, A.M.; Daloyau, M.; Miquel, M.-C.; Ronsin, B.; Wissinger, B.; Arnauné-Pelloquin, L.; Belenguer, P. OPA1 haploinsufficiency induces a BNIP3-dependent decrease in mitophagy in neurons: Relevance to Dominant Optic Atrophy. J. Neurochem. 2017, 140, 485-494. [CrossRef] [PubMed]

140. Liao, C.; Ashley, N.; Diot, A.; Morten, K.; Phadwal, K.; Williams, A.; Fearnley, I.; Rosser, L.; Lowndes, J.; Fratter, C.; et al. Dysregulated mitophagy and mitochondrial organization in optic atrophy due to OPA1 mutations. Neurology 2017, 88, 131-142. [CrossRef] [PubMed]

141. Pebay-Peyroula, E.; Dahout-Gonzalez, C.; Kahn, R.; Trézéguet, V.; Lauquin, G.J.M.; Brandolin, G. Structure of mitochondrial ADP / ATP carrier in complex with carboxyatractyloside. Nature 2003, 426, 39-44. [CrossRef]

142. Haitina, T.; Lindblom, J.; Renström, T.; Fredriksson, R. Fourteen novel human members of mitochondrial solute carrier family 25 (SLC25) widely expressed in the central nervous system. Genomics 2006, 88, 779-790. [CrossRef]

143. Abrams, A.J.; Hufnagel, R.B.; Rebelo, A.; Zanna, C.; Patel, N.; Gonzalez, M.A.; Campeanu, I.J.; Griffin, L.B.; Groenewald, S.; Strickland, A.V.; et al. Mutations in SLC25A46, encoding a UGO1-like protein, cause an optic atrophy spectrum disorder. Nat. Genet. 2015, 47, 926-932. [CrossRef] [PubMed]

144. Nguyen, M.; Boesten, I.; Hellebrekers, D.M.E.I.; Mulder-den Hartog, N.M.; de Coo, I.F.M.; Smeets, H.J.M.; Gerards, M. Novel pathogenic SLC25A46 splice-site mutation causes an optic atrophy spectrum disorder. Clin. Genet. 2017, 91, 121-125. [CrossRef]

145. Charlesworth, G.; Balint, B.; Mencacci, N.E.; Carr, L.; Wood, N.W.; Bhatia, K.P. SLC25A46 mutations underlie progressive myoclonic ataxia with optic atrophy and neuropathy. Mov. Disord. 2016, 31, 1249-1251. [CrossRef] [PubMed]

146. Hammer, M.B.; Ding, J.; Mochel, F.; Eleuch-Fayache, G.; Charles, P.; Coutelier, M.; Gibbs, J.R.; Arepalli, S.K.; Chong, S.B.; Hernandez, D.G.; et al. SLC25A46 Mutations Associated with Autosomal Recessive Cerebellar Ataxia in North African Families. Neurodegener. Dis. 2017, 17, 208-212. [CrossRef] [PubMed]

147. Wan, J.; Steffen, J.; Yourshaw, M.; Mamsa, H.; Andersen, E.; Rudnik-Schöneborn, S.; Pope, K.; Howell, K.B.; McLean, C.A.; Kornberg, A.J.; et al. Loss of function of SLC25A46 causes lethal congenital pontocerebellar hypoplasia. Brain 2016, 139, 2877-2890. [CrossRef] [PubMed]

148. Braunisch, M.C.; Gallwitz, H.; Abicht, A.; Diebold, I.; Holinski-Feder, E.; Van Maldergem, L.; Lammens, M.; Kovács-Nagy, R.; Alhaddad, B.; Strom, T.M.; et al. Extension of the phenotype of biallelic loss-of-function mutations in SLC25A46 to the severe form of pontocerebellar hypoplasia type I. Clin. Genet. 2018, 93, 255-265. [CrossRef] [PubMed]

149. Bitetto, G.; Malaguti, M.C.; Ceravolo, R.; Monfrini, E.; Straniero, L.; Morini, A.; Di Giacopo, R.; Frosini, D.; Palermo, G.; Biella, F.; et al. SLC25A46 mutations in patients with Parkinson's Disease and optic atrophy. Parkinsonism Relat. Disord. 2020, 74, 1-5. [CrossRef] [PubMed]

150. Duchesne, A.; Vaiman, A.; Castille, J.; Beauvallet, C.; Gaignard, P.; Floriot, S.; Rodriguez, S.; Vilotte, M.; Boulanger, L.; Passet, B.; et al. Bovine and murine models highlight novel roles for SLC25A46 in mitochondrial dynamics and metabolism, with implications for human and animal health. PLoS Genet. 2017, 13, e1006597. [CrossRef] [PubMed]

151. Terzenidou, M.E.; Segklia, A.; Kano, T.; Papastefanaki, F.; Karakostas, A.; Charalambous, M.; Ioakeimidis, F.; Papadaki, M.; Kloukina, I.; Chrysanthou-Piterou, M.; et al. Novel insights into SLC25A46-related pathologies in a genetic mouse model. PLoS Genet. 2017, 13, e1006656. [CrossRef]

152. Li, Z.; Peng, Y.; Hufnagel, R.B.; Hu, Y.-C.; Zhao, C.; Queme, L.F.; Khuchua, Z.; Driver, A.M.; Dong, F.; Lu, Q.R.; et al. Loss of SLC25A46 causes neurodegeneration by affecting mitochondrial dynamics and energy production in mice. Hum. Mol. Genet. 2017, 26, 3776-3791. [CrossRef] [PubMed]

153. Gao, L.; Wang, M.; Liao, L.; Gou, N.; Xu, P.; Ren, Z.; Yao, M.; Yuan, E.; Yang, X.; Ren, J. A Slc25a46-/- mouse model simulating motor deficit, imbalance of redox system and mitochondria dysfunction during aging. J. Gerontol. Ser. A 2020. [CrossRef]

154. Suda, K.; Ueoka, I.; Azuma, Y.; Muraoka, Y.; Yoshida, H.; Yamaguchi, M. Novel Drosophila model for mitochondrial diseases by targeting of a solute carrier protein SLC25A46. Brain Res. 2018, 1689, 30-44. [CrossRef] [PubMed]

155. Abrams, A.J.; Fontanesi, F.; Tan, N.B.L.; Buglo, E.; Campeanu, I.J.; Rebelo, A.P.; Kornberg, A.J.; Phelan, D.G.; Stark, Z.; Zuchner, S. Insights into the genotype-phenotype correlation and molecular function of SLC25A46. Hum. Mutat. 2018, 39, $1995-2007$. [CrossRef] [PubMed]

156. Gomes, L.C.; Benedetto, G.D.; Scorrano, L. During autophagy mitochondria elongate, are spared from degradation and sustain cell viability. Nat. Cell Biol. 2011, 13, 589-598. [CrossRef] [PubMed]

157. Rambold, A.S.; Kostelecky, B.; Elia, N.; Lippincott-Schwartz, J. Tubular network formation protects mitochondria from autophagosomal degradation during nutrient starvation. Proc. Natl. Acad. Sci. USA 2011, 108, 10190-10195. [CrossRef] [PubMed]

158. Taguchi, N.; Ishihara, N.; Jofuku, A.; Oka, T.; Mihara, K. Mitotic Phosphorylation of Dynamin-related GTPase Drp1 Participates in Mitochondrial Fission. J. Biol. Chem. 2007, 282, 11521-11529. [CrossRef] [PubMed]

159. Smirnova, E.; Griparic, L.; Shurland, D.L.; van der Bliek, A.M. Dynamin-related protein Drp1 is required for mitochondrial division in mammalian cells. Mol. Biol. Cell 2001, 12, 2245-2256. [CrossRef] [PubMed]

160. Kalia, R.; Wang, R.Y.-R.; Yusuf, A.; Thomas, P.V.; Agard, D.A.; Shaw, J.M.; Frost, A. Structural basis of mitochondrial receptor binding and constriction by DRP1. Nature 2018, 558, 401-405. [CrossRef] [PubMed]

161. Dimmer, K.S.; Navoni, F.; Casarin, A.; Trevisson, E.; Endele, S.; Winterpacht, A.; Salviati, L.; Scorrano, L. LETM1, deleted in Wolf-Hirschhorn syndrome is required for normal mitochondrial morphology and cellular viability. Hum. Mol. Genet. 2007, 17, 201-214. [CrossRef] [PubMed] 
162. Rival, T.; Macchi, M.; Arnauné-Pelloquin, L.; Poidevin, M.; Maillet, F.; Richard, F.; Fatmi, A.; Belenguer, P.; Royet, J. Innermembrane proteins PMI/TMEM11 regulate mitochondrial morphogenesis independently of the DRP1/MFN fission/fusion pathways. EMBO Rep. 2011, 12, 223-230. [CrossRef] [PubMed]

163. Stavru, F.; Bouillaud, F.; Sartori, A.; Ricquier, D.; Cossart, P. Listeria monocytogenes transiently alters mitochondrial dynamics during infection. Proc. Natl. Acad. Sci. USA 2011, 108, 3612-3617. [CrossRef] [PubMed]

164. Nakamura, K.; Nemani, V.M.; Azarbal, F.; Skibinski, G.; Levy, J.M.; Egami, K.; Munishkina, L.; Zhang, J.; Gardner, B.; Wakabayashi, J.; et al. Direct Membrane Association Drives Mitochondrial Fission by the Parkinson Disease-associated Protein $\alpha$-Synuclein. J. Biol. Chem. 2011, 286, 20710-20726. [CrossRef]

165. Stavru, F.; Palmer, A.E.; Wang, C.; Youle, R.J.; Cossart, P. Atypical mitochondrial fission upon bacterial infection. Proc. Natl. Acad. Sci. USA 2013, 110, 16003-16008. [CrossRef]

166. Roy, M.; Itoh, K.; Iijima, M.; Sesaki, H. Parkin suppresses Drp1-independent mitochondrial division. Biochem. Biophys. Res. Commun. 2016, 475, 283-288. [CrossRef] [PubMed]

167. Friedman, J.R.; Lackner, L.L.; West, M.; DiBenedetto, J.R.; Nunnari, J.; Voeltz, G.K. ER Tubules Mark Sites of Mitochondrial Division. Science 2011, 334, 358-362. [CrossRef] [PubMed]

168. Basu, K.; Lajoie, D.; Aumentado-Armstrong, T.; Chen, J.; Koning, R.I.; Bossy, B.; Bostina, M.; Sik, A.; Bossy-Wetzel, E.; Rouiller, I. Molecular mechanism of DRP1 assembly studied in vitro by cryo-electron microscopy. PLoS ONE 2017, 12, e0179397. [CrossRef] [PubMed]

169. Manor, U.; Bartholomew, S.; Golani, G.; Christenson, E.; Kozlov, M.; Higgs, H.; Spudich, J.; Lippincott-Schwartz, J. A mitochondriaanchored isoform of the actin-nucleating spire protein regulates mitochondrial division. eLife 2015, 4, e08828. [CrossRef] [PubMed]

170. Korobova, F.; Ramabhadran, V.; Higgs, H.N. An Actin-Dependent Step in Mitochondrial Fission Mediated by the ER-Associated Formin INF2. Science 2013, 339, 464-467. [CrossRef] [PubMed]

171. Schiavon, C.R.; Zhang, T.; Zhao, B.; Moore, A.S.; Wales, P.; Andrade, L.R.; Wu, M.; Sung, T.-C.; Dayn, Y.; Feng, J.W. Actin chromobody imaging reveals sub-organellar actin dynamics. Nat. Methods 2020, 17, 917-921. [CrossRef]

172. Korobova, F.; Gauvin, T.J.; Higgs, H.N. A Role for Myosin II in Mammalian Mitochondrial Fission. Curr. Biol. 2014, $24,409-414$. [CrossRef] [PubMed]

173. Almutawa, W.; Smith, C.; Sabouny, R.; Smit, R.B.; Zhao, T.; Wong, R.; Lee-Glover, L.; Desrochers-Goyette, J.; Ilamathi, H.S.; Suchowersky, O.; et al. The R941L mutation in MYH14 disrupts mitochondrial fission and associates with peripheral neuropathy. EBioMedicine 2019, 45, 379-392. [CrossRef] [PubMed]

174. Losón, O.C.; Song, Z.; Chen, H.; Chan, D.C. Fis1, Mff, MiD49, and MiD51 mediate Drp1 recruitment in mitochondrial fission. Mol. Biol. Cell 2013, 24, 659-667. [CrossRef] [PubMed]

175. Richter, V.; Singh, A.P.; Kvansakul, M.; Ryan, M.T.; Osellame, L.D. Splitting up the powerhouse: Structural insights into the mechanism of mitochondrial fission. Cell. Mol. Life Sci. 2015, 72, 3695-3707. [CrossRef] [PubMed]

176. Kraus, F.; Ryan, M.T. The constriction and scission machineries involved in mitochondrial fission. J. Cell Sci. 2017, 130, 2953-2960. [CrossRef] [PubMed]

177. Mozdy, A.D.; McCaffery, J.M.; Shaw, J.M. Dnm1p Gtpase-Mediated Mitochondrial Fission Is a Multi-Step Process Requiring the Novel Integral Membrane Component Fis1p. J. Cell Biol. 2000, 151, 367-380. [CrossRef] [PubMed]

178. Zhang, Y.; Chan, D.C. Structural basis for recruitment of mitochondrial fission complexes by Fis1. Proc. Natl. Acad. Sci. USA 2007, 104, 18526-18530. [CrossRef]

179. Otera, H.; Wang, C.; Cleland, M.M.; Setoguchi, K.; Yokota, S.; Youle, R.J.; Mihara, K. Mff is an essential factor for mitochondrial recruitment of Drp1 during mitochondrial fission in mammalian cells. J. Cell Biol. 2010, 191, 1141-1158. [CrossRef]

180. Osellame, L.D.; Singh, A.P.; Stroud, D.A.; Palmer, C.S.; Stojanovski, D.; Ramachandran, R.; Ryan, M.T. Cooperative and independent roles of the Drp1 adaptors Mff, MiD49 and MiD51 in mitochondrial fission. J. Cell Sci. 2016, 129, $2170-2181$. [CrossRef]

181. Qi, X.; Qvit, N.; Su, Y.-C.; Mochly-Rosen, D. A novel Drp1 inhibitor diminishes aberrant mitochondrial fission and neurotoxicity. J. Cell Sci. 2013, 126, 789-802. [CrossRef]

182. Shen, Q.; Yamano, K.; Head, B.P.; Kawajiri, S.; Cheung, J.T.M.; Wang, C.; Cho, J.-H.; Hattori, N.; Youle, R.J.; Bliek, A.M.v.d. Mutations in Fis1 disrupt orderly disposal of defective mitochondria. Mol. Biol. Cell 2014, 25, 145-159. [CrossRef] [PubMed]

183. Yamano, K.; Fogel, A.I.; Wang, C.; van der Bliek, A.M.; Youle, R.J. Mitochondrial Rab GAPs govern autophagosome biogenesis during mitophagy. eLife 2014, 3, e01612. [CrossRef]

184. Palmer, C.S.; Osellame, L.D.; Laine, D.; Koutsopoulos, O.S.; Frazier, A.E.; Ryan, M.T. MiD49 and MiD51, new components of the mitochondrial fission machinery. EMBO Rep. 2011, 12, 565-573. [CrossRef] [PubMed]

185. Palmer, C.S.; Elgass, K.D.; Parton, R.G.; Osellame, L.D.; Stojanovski, D.; Ryan, M.T. Adaptor Proteins MiD49 and MiD51 Can Act Independently of Mff and Fis1 in Drp1 Recruitment and Are Specific for Mitochondrial Fission. J. Biol. Chem. 2013, 288, 27584-27593. [CrossRef]

186. Niemann, A.; Ruegg, M.; La Padula, V.; Schenone, A.; Suter, U. Ganglioside-induced differentiation associated protein 1 is a regulator of the mitochondrial network: New implications for Charcot-Marie-Tooth disease. J. Cell Biol. 2005, 170, 1067-1078. [CrossRef]

187. Niemann, A.; Wagner, K.M.; Ruegg, M.; Suter, U. GDAP1 mutations differ in their effects on mitochondrial dynamics and apoptosis depending on the mode of inheritance. Neurobiol. Dis. 2009, 36, 509-520. [CrossRef] [PubMed] 
188. Charif, M.; Wong, Y.C.; Kim, S.; Guichet, A.; Vignal, C.; Zanlonghi, X.; Bensaid, P.; Procaccio, V.; Bonneau, D.; Amati-Bonneau, P. Dominant mutations in MIEF1 affect mitochondrial dynamics and cause a singular late onset optic neuropathy. Mol. Neurodegener. 2021, 16, 1-9. [CrossRef] [PubMed]

189. Lee, J.E.; Westrate, L.M.; Wu, H.; Page, C.; Voeltz, G.K. Multiple dynamin family members collaborate to drive mitochondrial division. Nature 2016, 540, 139. [CrossRef] [PubMed]

190. Fonseca, T.B.; Sánchez-Guerrero, Á.; Milosevic, I.; Raimundo, N. Mitochondrial fission requires DRP1 but not dynamins. Nature 2019, 570, E34-E42. [CrossRef] [PubMed]

191. Kamerkar, S.C.; Kraus, F.; Sharpe, A.J.; Pucadyil, T.J.; Ryan, M.T. Dynamin-related protein 1 has membrane constricting and severing abilities sufficient for mitochondrial and peroxisomal fission. Nat. Commun. 2018, 9, 5239. [CrossRef] [PubMed]

192. Wagner, K.M.; Rüegg, M.; Niemann, A.; Suter, U. Targeting and Function of the Mitochondrial Fission Factor GDAP1 Are Dependent on Its Tail-Anchor. PLoS ONE 2009, 4, e5160. [CrossRef]

193. Shield, A.J.; Murray, T.P.; Board, P.G. Functional characterisation of ganglioside-induced differentiation-associated protein 1 as a glutathione transferase. Biochem. Biophys. Res. Commun. 2006, 347, 859-866. [CrossRef] [PubMed]

194. Marco, A.; Cuesta, A.; Pedrola, L.; Palau, F.; Marín, I. Evolutionary and Structural Analyses of GDAP1, Involved in CharcotMarie-Tooth Disease, Characterize a Novel Class of Glutathione Transferase-Related Genes. Mol. Biol. Evol. 2004, 21 , 176-187. [CrossRef] [PubMed]

195. Huber, N.; Bieniossek, C.; Wagner, K.M.; Elsässer, H.-P.; Suter, U.; Berger, I.; Niemann, A. Glutathione-conjugating and membraneremodeling activity of GDAP1 relies on amphipathic C-terminal domain. Sci. Rep. 2016, 6, 36930. [CrossRef] [PubMed]

196. Niemann, A.; Huber, N.; Wagner, K.M.; Somandin, C.; Horn, M.; Lebrun-Julien, F.; Angst, B.; Pereira, J.A.; Halfter, H.; Welzl, H.; et al. The Gdap1 knockout mouse mechanistically links redox control to Charcot-Marie-Tooth disease. Brain 2014, 137, 668-682. [CrossRef] [PubMed]

197. Wolf, C.; López Del Amo, V.; Arndt, S.; Bueno, D.; Tenzer, S.; Hanschmann, E.-M.; Berndt, C.; Methner, A. Redox modifications of proteins of the mitochondrial fusion and fission machinery. Cells 2020, 9, 815. [CrossRef] [PubMed]

198. Huber, N.; Guimaraes, S.; Schrader, M.; Suter, U.; Niemann, A. Charcot-Marie-Tooth disease-associated mutants of GDAP1 dissociate its roles in peroxisomal and mitochondrial fission. EMBO Rep. 2013, 14, 545-552. [CrossRef] [PubMed]

199. Pla-Martín, D.; Rueda, C.B.; Estela, A.; Sánchez-Piris, M.; González-Sánchez, P.; Traba, J.; de la Fuente, S.; Scorrano, L.; Renau-Piqueras, J.; Alvarez, J.; et al. Silencing of the Charcot-Marie-Tooth disease-associated gene GDAP1 induces abnormal mitochondrial distribution and affects Ca2+ homeostasis by reducing store-operated Ca2+ entry. Neurobiol. Dis. 2013, 55, 140-151. [CrossRef] [PubMed]

200. Barneo-Muñoz, M.; Juárez, P.; Civera-Tregón, A.; Yndriago, L.; Pla-Martin, D.; Zenker, J.; Cuevas-Martín, C.; Estela, A.; SánchezAragó, M.; Forteza-Vila, J.; et al. Lack of GDAP1 Induces Neuronal Calcium and Mitochondrial Defects in a Knockout Mouse Model of Charcot-Marie-Tooth Neuropathy. PLoS Genet. 2015, 11, e1005115. [CrossRef] [PubMed]

201. Estela, A.; Pla-Martín, D.; Sánchez-Piris, M.; Sesaki, H.; Palau, F. Charcot-Marie-Tooth-related gene GDAP1 complements cell cycle delay at G2/M phase in Saccharomyces cerevisiae fis1 gene-defective cells. J. Biol. Chem. 2011, 286, 36777-36786. [CrossRef]

202. Baxter, R.V.; Ben Othmane, K.; Rochelle, J.M.; Stajich, J.E.; Hulette, C.; Dew-Knight, S.; Hentati, F.; Ben Hamida, M.; Bel, S.; Stenger, J.E.; et al. Ganglioside-induced differentiation-associated protein-1 is mutant in Charcot-Marie-Tooth disease type 4A/8q21. Nat. Genet. 2002, 30, 21-22. [CrossRef]

203. Cuesta, A.; Pedrola, L.; Sevilla, T.; García-Planells, J.; Chumillas, M.J.; Mayordomo, F.; LeGuern, E.; Marín, I.; Vílchez, J.J.; Palau, F. The gene encoding ganglioside-induced differentiation-associated protein 1 is mutated in axonal Charcot-Marie-Tooth type $4 \mathrm{~A}$ disease. Nat. Genet. 2002, 30, 22-25. [CrossRef] [PubMed]

204. Sivera, R.; Frasquet, M.; Lupo, V.; García-Sobrino, T.; Blanco-Arias, P.; Pardo, J.; Fernández-Torrón, R.; De Munain, A.L.; MárquezInfante, C.; Villarreal, L. Distribution and genotype-phenotype correlation of GDAP1 mutations in Spain. Sci. Rep. 2017, 7, 1-10. [CrossRef]

205. Claramunt, R.; Pedrola, L.; Sevilla, T.; de Munain, A.L.; Berciano, J.; Cuesta, A.; Sanchez-Navarro, B.; Millan, J.M.; Saifi, G.M.; Lupski, J.R. Genetics of Charcot-Marie-Tooth disease type 4A: Mutations, inheritance, phenotypic variability, and founder effect. J. Med. Genet. 2005, 42, 358-365. [CrossRef]

206. Marttila, M.; Kytövuori, L.; Helisalmi, S.; Kallio, M.; Laitinen, M.; Hiltunen, M.; Kärppä, M.; Majamaa, K. Molecular epidemiology of Charcot-Marie-Tooth disease in Northern Ostrobothnia, Finland: A population-based study. Neuroepidemiology 2017, 49, 34-39. [CrossRef] [PubMed]

207. Fernandez-Lizarbe, S.; Civera-Tregón, A.; Cantarero, L.; Herrer, I.; Juarez, P.; Hoenicka, J.; Palau, F. Neuroinflammation in the pathogenesis of axonal Charcot-Marie-Tooth disease caused by lack of GDAP1. Exp. Neurol. 2019, 320, 113004. [CrossRef] [PubMed]

208. Eijkenboom, I.; Vanoevelen, J.M.; Hoeijmakers, J.G.J.; Wijnen, I.; Gerards, M.; Faber, C.G.; Smeets, H.J.M. A zebrafish model to study small-fiber neuropathy reveals a potential role for GDAP1. Mitochondrion 2019, 47, 273-281. [CrossRef] [PubMed]

209. López del Amo, V.; Palomino-Schätzlein, M.; Seco-Cervera, M.; García-Giménez, J.L.; Pallardó, F.V.; Pineda-Lucena, A.; Galindo, M.I. A Drosophila model of GDAP1 function reveals the involvement of insulin signalling in the mitochondria-dependent neuromuscular degeneration. Biochim. Biophys. Acta (BBA) Mol. Basis Dis. 2017, 1863, 801-809. [CrossRef] [PubMed]

210. Labrousse, A.M.; Zappaterra, M.D.; Rube, D.A.; van der Bliek, A.M.C. elegans Dynamin-Related Protein DRP-1 Controls Severing of the Mitochondrial Outer Membrane. Mol. Cell 1999, 4, 815-826. [CrossRef] 
211. Sesaki, H.; Jensen, R.E. Division versus Fusion: Dnm1p and Fzo1p Antagonistically Regulate Mitochondrial Shape. J. Cell Biol. 1999, 147, 699-706. [CrossRef]

212. Bleazard, W.; McCaffery, J.M.; King, E.J.; Bale, S.; Mozdy, A.; Tieu, Q.; Nunnari, J.; Shaw, J.M. The dynamin-related GTPase Dnm1 regulates mitochondrial fission in yeast. Nat. Cell Biol. 1999, 1, 298-304. [CrossRef] [PubMed]

213. Koch, A.; Thiemann, M.; Grabenbauer, M.; Yoon, Y.; McNiven, M.A.; Schrader, M. Dynamin-like Protein 1 Is Involved in Peroxisomal Fission. J. Biol. Chem. 2003, 278, 8597-8605. [CrossRef]

214. Li, X.; Gould, S.J. The Dynamin-like GTPase DLP1 Is Essential for Peroxisome Division and Is Recruited to Peroxisomes in Part by PEX11. J. Biol. Chem. 2003, 278, 17012-17020. [CrossRef] [PubMed]

215. Chao, Y.-H.; Robak, L.A.; Xia, F.; Koenig, M.K.; Adesina, A.; Bacino, C.A.; Scaglia, F.; Bellen, H.J.; Wangler, M.F. Missense variants in the middle domain of DNM1L in cases of infantile encephalopathy alter peroxisomes and mitochondria when assayed in Drosophila. Hum. Mol. Genet. 2016, 25, 1846-1856. [CrossRef] [PubMed]

216. Sheffer, R.; Douiev, L.; Edvardson, S.; Shaag, A.; Tamimi, K.; Soiferman, D.; Meiner, V.; Saada, A. Postnatal microcephaly and pain insensitivity due to a de novo heterozygous DNM1L mutation causing impaired mitochondrial fission and function. Am. J. Med. Genet. Part A 2016, 170, 1603-1607. [CrossRef] [PubMed]

217. Vanstone, J.R.; Smith, A.M.; McBride, S.; Naas, T.; Holcik, M.; Antoun, G.; Harper, M.-E.; Michaud, J.; Sell, E.; Chakraborty, P.; et al. DNM1L-related mitochondrial fission defect presenting as refractory epilepsy. Eur. J. Hum. Genet. 2016, 24, 1084-1088. [CrossRef] [PubMed]

218. Fahrner, J.A.; Liu, R.; Perry, M.S.; Klein, J.; Chan, D.C. A novel de novo dominant negative mutation in DNM1L impairs mitochondrial fission and presents as childhood epileptic encephalopathy. Am. J. Med. Genet. Part A 2016, 170, $2002-2011$. [CrossRef]

219. Longo, F.; Benedetti, S.; Zambon, A.A.; Sora, M.G.N.; Di Resta, C.; De Ritis, D.; Quattrini, A.; Maltecca, F.; Ferrari, M.; Previtali, S.C. Impaired turnover of hyperfused mitochondria in severe axonal neuropathy due to a novel DRP1 mutation. Hum. Mol. Genet. 2019, 29, 177-188. [CrossRef] [PubMed]

220. Assia Batzir, N.; Bhagwat, P.K.; Eble, T.N.; Liu, P.; Eng, C.M.; Elsea, S.H.; Robak, L.A.; Scaglia, F.; Goldman, A.M.; Dhar, S.U.; et al. De novo missense variant in the GTPase effector domain (GED) of DNM1L leads to static encephalopathy and seizures. Mol. Case Stud. 2019, 5. [CrossRef]

221. Whitley, B.N.; Lam, C.; Cui, H.; Haude, K.; Bai, R.; Escobar, L.; Hamilton, A.; Brady, L.; Tarnopolsky, M.A.; Dengle, L.; et al. Aberrant Drp1-mediated mitochondrial division presents in humans with variable outcomes. Hum. Mol. Genet. 2018, 27, 3710-3719. [CrossRef]

222. Ladds, E.; Whitney, A.; Dombi, E.; Hofer, M.; Anand, G.; Harrison, V.; Fratter, C.; Carver, J.; Barbosa, I.A.; Simpson, M.; et al. De novo DNM1L mutation associated with mitochondrial epilepsy syndrome with fever sensitivity. Neurol. Genet. 2018, 4, e258. [CrossRef]

223. Schmid, S.J.; Wagner, M.; Goetz, C.; Makowski, C.; Freisinger, P.; Berweck, S.; Mall, V.; Burdach, S.; Juenger, H. A De Novo Dominant Negative Mutation in DNM1L Causes Sudden Onset Status Epilepticus with Subsequent Epileptic Encephalopathy. Neuropediatrics 2019, 50, 197-201. [CrossRef]

224. Nasca, A.; Legati, A.; Baruffini, E.; Nolli, C.; Moroni, I.; Ardissone, A.; Goffrini, P.; Ghezzi, D. Biallelic Mutations in DNM1L are Associated with a Slowly Progressive Infantile Encephalopathy. Hum. Mutat. 2016, 37, 898-903. [CrossRef] [PubMed]

225. Verrigni, D.; Di Nottia, M.; Ardissone, A.; Baruffini, E.; Nasca, A.; Legati, A.; Bellacchio, E.; Fagiolari, G.; Martinelli, D.; Fusco, L.; et al. Clinical-genetic features and peculiar muscle histopathology in infantile DNM1L-related mitochondrial epileptic encephalopathy. Hum. Mutat. 2019, 40, 601-618. [CrossRef] [PubMed]

226. Gerber, S.; Charif, M.; Chevrollier, A.; Chaumette, T.; Angebault, C.; Kane, M.S.; Paris, A.; Alban, J.; Quiles, M.; Delettre, C.; et al. Mutations in DNM1L, as in OPA1, result in dominant optic atrophy despite opposite effects on mitochondrial fusion and fission. Brain 2017, 140, 2586-2596. [CrossRef] [PubMed]

227. Hogarth, K.A.; Costford, S.R.; Yoon, G.; Sondheimer, N.; Maynes, J.T. DNM1L Variant Alters Baseline Mitochondrial Function and Response to Stress in a Patient with Severe Neurological Dysfunction. Biochem. Genet. 2018, 56, 56-77. [CrossRef]

228. Chang, C.-R.; Manlandro, C.M.; Arnoult, D.; Stadler, J.; Posey, A.E.; Hill, R.B.; Blackstone, C. A Lethal de novo Mutation in the Middle Domain of the Dynamin-related GTPase Drp1 Impairs Higher Order Assembly and Mitochondrial Division. J. Biol. Chem. 2010, 285, 32494-32503. [CrossRef]

229. Yoon, G.; Malam, Z.; Paton, T.; Marshall, C.R.; Hyatt, E.; Ivakine, Z.; Scherer, S.W.; Lee, K.-S.; Hawkins, C.; Cohn, R.D.; et al. Lethal Disorder of Mitochondrial Fission Caused by Mutations in DNM1L. J. Pediatrics 2016, 171, 313-316.e312. [CrossRef] [PubMed]

230. Ryan, C.S.; Fine, A.L.; Cohen, A.L.; Schiltz, B.M.; Renaud, D.L.; Wirrell, E.C.; Patterson, M.C.; Boczek, N.J.; Liu, R.; BabovicVuksanovic, D.; et al. De Novo DNM1L Variant in a Teenager With Progressive Paroxysmal Dystonia and Lethal Super-refractory Myoclonic Status Epilepticus. J. Child Neurol. 2018, 33, 651-658. [CrossRef] [PubMed]

231. Danielle, A.N.; Baibing, C.; Anne Marie, M.; Emily, S.; Daniel, A. A Rasmussen encephalitis, autoimmune encephalitis, and mitochondrial disease mimicker: Expanding the DNM1L-associated intractable epilepsy and encephalopathy phenotype. Epileptic Disord. 2019, 21, 112-116. [CrossRef]

232. Ashrafian, H.; Docherty, L.; Leo, V.; Towlson, C.; Neilan, M.; Steeples, V.; Lygate, C.A.; Hough, T.; Townsend, S.; Williams, D. A mutation in the mitochondrial fission gene Dnm1l leads to cardiomyopathy. PLoS Genet. 2010, 6, 655-670. [CrossRef] 
233. Quadir, A.; Pontifex, C.S.; Robertson, H.L.; Labos, C.; Pfeffer, G. Systematic review and meta-analysis of cardiac involvement in mitochondrial myopathy. Neurol. Genet. 2019, 5, 2376-7839. [CrossRef]

234. Wei, Y.; Qian, M. Case Report: A Novel de novo Mutation in DNM1L Presenting With Developmental Delay, Ataxia, and Peripheral Neuropathy. Front. Pediatrics 2021, 9. [CrossRef] [PubMed]

235. Berthet, A.; Margolis, E.B.; Zhang, J.; Hsieh, I.; Zhang, J.; Hnasko, T.S.; Ahmad, J.; Edwards, R.H.; Sesaki, H.; Huang, E.J.; et al. Loss of Mitochondrial Fission Depletes Axonal Mitochondria in Midbrain Dopamine Neurons. J. Neurosci. 2014, 34, 14304-14317. [CrossRef] [PubMed]

236. Oettinghaus, B.; Schulz, J.M.; Restelli, L.M.; Licci, M.; Savoia, C.; Schmidt, A.; Schmitt, K.; Grimm, A.; Morè, L.; Hench, J.; et al. Synaptic dysfunction, memory deficits and hippocampal atrophy due to ablation of mitochondrial fission in adult forebrain neurons. Cell Death Differ. 2016, 23, 18-28. [CrossRef]

237. Shields, L.Y.; Kim, H.; Zhu, L.; Haddad, D.; Berthet, A.; Pathak, D.; Lam, M.; Ponnusamy, R.; Diaz-Ramirez, L.G.; Gill, T.M.; et al. Dynamin-related protein 1 is required for normal mitochondrial bioenergetic and synaptic function in CA1 hippocampal neurons. Cell Death Dis. 2015, 6, e1725. [CrossRef] [PubMed]

238. Tarailo-Graovac, M.; Zahir, F.R.; Zivkovic, I.; Moksa, M.; Selby, K.; Sinha, S.; Nislow, C.; Stockler-Ipsiroglu, S.G.; Sheffer, R.; Saada-Reisch, A.; et al. De novo pathogenic DNM1L variant in a patient diagnosed with atypical hereditary sensory and autonomic neuropathy. Mol. Genet. Genom. Med. 2019, 7, e00961. [CrossRef] [PubMed]

239. Ferrari, L.F.; Chum, A.; Bogen, O.; Reichling, D.B.; Levine, J.D. Role of Drp1, a key mitochondrial fission protein, in neuropathic pain. J. Neurosci. 2011, 31, 11404-11410. [CrossRef] [PubMed]

240. Gandre-Babbe, S.; Bliek, A.M.v.d. The Novel Tail-anchored Membrane Protein Mff Controls Mitochondrial and Peroxisomal Fission in Mammalian Cells. Mol. Biol. Cell 2008, 19, 2402-2412. [CrossRef] [PubMed]

241. Zhang, Z.; Liu, L.; Wu, S.; Xing, D. Drp1, Mff, Fis1, and MiD51 are coordinated to mediate mitochondrial fission during UV irradiation-induced apoptosis. FASEB J. 2016, 30, 466-476. [CrossRef] [PubMed]

242. Hardie, D.G.; Ross, F.A.; Hawley, S.A. AMPK: A nutrient and energy sensor that maintains energy homeostasis. Nat. Rev. Mol. Cell Biol. 2012, 13, 251-262. [CrossRef] [PubMed]

243. Ducommun, S.; Deak, M.; Sumpton, D.; Ford, R.J.; Núñez Galindo, A.; Kussmann, M.; Viollet, B.; Steinberg, G.R.; Foretz, M.; Dayon, L.; et al. Motif affinity and mass spectrometry proteomic approach for the discovery of cellular AMPK targets: Identification of mitochondrial fission factor as a new AMPK substrate. Cell. Signal. 2015, 27, 978-988. [CrossRef]

244. Shamseldin, H.E.; Alshammari, M.; Al-Sheddi, T.; Salih, M.A.; Alkhalidi, H.; Kentab, A.; Repetto, G.M.; Hashem, M.; Alkuraya, F.S. Genomic analysis of mitochondrial diseases in a consanguineous population reveals novel candidate disease genes. J. Med. Genet. 2012, 49, 234-241. [CrossRef] [PubMed]

245. Nasca, A.; Nardecchia, F.; Commone, A.; Semeraro, M.; Legati, A.; Garavaglia, B.; Ghezzi, D.; Leuzzi, V. Clinical and Biochemical Features in a Patient With Mitochondrial Fission Factor Gene Alteration. Front. Genet. 2018, 9. [CrossRef] [PubMed]

246. Panda, I.; Ahmad, I.; Sagar, S.; Zahra, S.; Shamim, U.; Sharma, S.; Faruq, M. Encephalopathy due to defective mitochondrial and peroxisomal fission 2 caused by a novel MFF gene mutation in a young child. Clin. Genet. 2020, 97, 933-937. [CrossRef] [PubMed]

247. Chen, H.; Ren, S.; Clish, C.; Jain, M.; Mootha, V.; McCaffery, J.M.; Chan, D.C. Titration of mitochondrial fusion rescues Mff-deficient cardiomyopathy. J. Cell Biol. 2015, 211, 795-805. [CrossRef]

248. Hinshaw, J.E. Dynamin and Its Role in Membrane Fission. Annu. Rev. Cell Dev. Biol. 2000, 16, 483-519. [CrossRef] [PubMed]

249. Schafer, D.A.; Weed, S.A.; Binns, D.; Karginov, A.V.; Parsons, J.T.; Cooper, J.A. Dynamin2 and Cortactin Regulate Actin Assembly and Filament Organization. Curr. Biol. 2002, 12, 1852-1857. [CrossRef]

250. Thompson, H.M.; Cao, H.; Chen, J.; Euteneuer, U.; McNiven, M.A. Dynamin 2 binds $\gamma$-tubulin and participates in centrosome cohesion. Nat. Cell Biol. 2004, 6, 335-342. [CrossRef] [PubMed]

251. Ferguson, S.; Raimondi, A.; Paradise, S.; Shen, H.; Mesaki, K.; Ferguson, A.; Destaing, O.; Ko, G.; Takasaki, J.; Cremona, O.; et al. Coordinated Actions of Actin and BAR Proteins Upstream of Dynamin at Endocytic Clathrin-Coated Pits. Dev. Cell 2009, 17, 811-822. [CrossRef]

252. Fabrizi, G.M.; Ferrarini, M.; Cavallaro, T.; Cabrini, I.; Cerini, R.; Bertolasi, L.; Rizzuto, N. Two novel mutations in dynamin-2 cause axonal Charcot-Marie-Tooth disease. Neurology 2007, 69, 291-295. [CrossRef]

253. Bitoun, M.; Stojkovic, T.; Prudhon, B.; Maurage, C.-A.; Latour, P.; Vermersch, P.; Guicheney, P. A novel mutation in the dynamin 2 gene in a Charcot-Marie-Tooth type 2 patient: Clinical and pathological findings. Neuromuscul. Disord. 2008, 18, 334-338. [CrossRef] [PubMed]

254. Gallardo, E.; Claeys, K.G.; Nelis, E.; García, A.; Canga, A.; Combarros, O.; Timmerman, V.; De Jonghe, P.; Berciano, J. Magnetic resonance imaging findings of leg musculature in Charcot-Marie-Tooth disease type 2 due to dynamin 2 mutation. J. Neurol. 2008, 255, 986. [CrossRef]

255. Claeys, K.G.; Züchner, S.; Kennerson, M.; Berciano, J.; Garcia, A.; Verhoeven, K.; Storey, E.; Merory, J.R.; Bienfait, H.M.E.; Lammens, M.; et al. Phenotypic spectrum of dynamin 2 mutations in Charcot-Marie-Tooth neuropathy. Brain 2009, 132, 1741-1752. [CrossRef] [PubMed]

256. Züchner, S.; Noureddine, M.; Kennerson, M.; Verhoeven, K.; Claeys, K.; Jonghe, P.D.; Merory, J.; Oliveira, S.A.; Speer, M.C.; Stenger, J.E.; et al. Mutations in the pleckstrin homology domain of dynamin 2 cause dominant intermediate Charcot-Marie-Tooth disease. Nat. Genet. 2005, 37, 289-294. [CrossRef] 
257. Echaniz-Laguna, A.; Nicot, A.-S.; Carré, S.; Franques, J.; Tranchant, C.; Dondaine, N.; Biancalana, V.; Mandel, J.-L.; Laporte, J. Subtle central and peripheral nervous system abnormalities in a family with centronuclear myopathy and a novel dynamin 2 gene mutation. Neuromuscul. Disord. 2007, 17, 955-959. [CrossRef] [PubMed]

258. Bitoun, M.; Bevilacqua, J.A.; Prudhon, B.; Maugenre, S.; Taratuto, A.L.; Monges, S.; Lubieniecki, F.; Cances, C.; Uro-Coste, E.; Mayer, M.; et al. Dynamin 2 mutations cause sporadic centronuclear myopathy with neonatal onset. Ann. Neurol. 2007, 62, 666-670. [CrossRef] [PubMed]

259. Jungbluth, H.; Cullup, T.; Lillis, S.; Zhou, H.; Abbs, S.; Sewry, C.; Muntoni, F. Centronuclear myopathy with cataracts due to a novel dynamin 2 (DNM2) mutation. Neuromuscul. Disord. 2010, 20, 49-52. [CrossRef]

260. Gerber, D.; Ghidinelli, M.; Tinelli, E.; Somandin, C.; Gerber, J.; Pereira, J.A.; Ommer, A.; Figlia, G.; Miehe, M.; Nägeli, L.G.; et al. Schwann cells, but not Oligodendrocytes, Depend Strictly on Dynamin 2 Function. eLife 2019, 8, e42404. [CrossRef]

261. Pruyne, D.; Evangelista, M.; Yang, C.; Bi, E.; Zigmond, S.; Bretscher, A.; Boone, C. Role of Formins in Actin Assembly: Nucleation and Barbed-End Association. Science 2002, 297, 612-615. [CrossRef] [PubMed]

262. Ramabhadran, V.; Korobova, F.; Rahme, G.J.; Higgs, H.N. Splice variant-specific cellular function of the formin INF2 in maintenance of Golgi architecture. Mol. Biol. Cell 2011, 22, 4822-4833. [CrossRef]

263. Chhabra, E.S.; Ramabhadran, V.; Gerber, S.A.; Higgs, H.N. INF2 is an endoplasmic reticulum-associated formin protein. J. Cell Sci. 2009, 122, 1430-1440. [CrossRef]

264. Chakrabarti, R.; Ji, W.-K.; Stan, R.V.; de Juan Sanz, J.; Ryan, T.A.; Higgs, H.N. INF2-mediated actin polymerization at the ER stimulates mitochondrial calcium uptake, inner membrane constriction, and division. J. Cell Biol. 2017, 217, 251-268. [CrossRef] [PubMed]

265. Steffen, J.; Koehler, C.M. ER-mitochondria contacts: Actin dynamics at the ER control mitochondrial fission via calcium release. J. Cell Biol. 2017, 217, 15-17. [CrossRef] [PubMed]

266. Higgs, H.N. Formin proteins: A domain-based approach. Trends Biochem. Sci. 2005, 30, 342-353. [CrossRef] [PubMed]

267. Chhabra, E.S.; Higgs, H.N. INF2 Is a WASP Homology 2 Motif-containing Formin That Severs Actin Filaments and Accelerates Both Polymerization and Depolymerization. J. Biol. Chem. 2006, 281, 26754-26767. [CrossRef] [PubMed]

268. Ramabhadran, V.; Hatch, A.L.; Higgs, H.N. Actin Monomers Activate Inverted Formin 2 by Competing with Its Autoinhibitory Interaction. J. Biol. Chem. 2013, 288, 26847-26855. [CrossRef] [PubMed]

269. Boyer, O.; Nevo, F.; Plaisier, E.; Funalot, B.; Gribouval, O.; Benoit, G.; Cong, E.H.; Arrondel, C.; Tête, M.-J.; Montjean, R.; et al. INF2 Mutations in Charcot-Marie-Tooth Disease with Glomerulopathy. N. Engl. J. Med. 2011, 365, 2377-2388. [CrossRef]

270. Labat-de-Hoz, L.; Alonso, M.A. The formin INF2 in disease: Progress from 10 years of research. Cell. Mol. Life Sci. 2020, 77, 4581-4600. [CrossRef]

271. Boyer, O.; Benoit, G.; Gribouval, O.; Nevo, F.; Tête, M.-J.; Dantal, J.; Gilbert-Dussardier, B.; Touchard, G.; Karras, A.; Presne, C.; et al. Mutations in INF2 Are a Major Cause of Autosomal Dominant Focal Segmental Glomerulosclerosis. J. Am. Soc. Nephrol. 2011, 22, 239-245. [CrossRef]

272. Rollason, R.; Wherlock, M.; Heath, J.A.; Heesom, K.J.; Saleem, M.A.; Welsh, G.I. Disease causing mutations in inverted formin 2 regulate its binding to G-actin, F-actin capping protein (CapZ $\alpha-1)$ and profilin 2. Biosci. Rep. 2016, 36. [CrossRef] [PubMed]

273. Bayraktar, S.; Nehrig, J.; Menis, E.; Karli, K.; Janning, A.; Struk, T.; Halbritter, J.; Michgehl, U.; Krahn, M.P.; Schuberth, C.E. A Deregulated Stress Response Underlies Distinct INF2-Associated Disease Profiles. J. Am. Soc. Nephrol. 2020, 31, 1296-1313. [CrossRef] [PubMed]

274. Kneussel, M.; Wagner, W. Myosin motors at neuronal synapses: Drivers of membrane transport and actin dynamics. Nat. Rev. Neurosci. 2013, 14, 233-247. [CrossRef]

275. Donaudy, F.; Snoeckx, R.; Pfister, M.; Zenner, H.-P.; Blin, N.; Di Stazio, M.; Ferrara, A.; Lanzara, C.; Ficarella, R.; Declau, F.; et al. Nonmuscle Myosin Heavy-Chain Gene MYH14 Is Expressed in Cochlea and Mutated in Patients Affected by Autosomal Dominant Hearing Impairment (DFNA4). Am. J. Hum. Genet. 2004, 74, 770-776. [CrossRef] [PubMed]

276. Kim, B.J.; Kim, A.R.; Han, J.H.; Lee, C.; Oh, D.Y.; Choi, B.Y. Discovery of MYH14 as an important and unique deafness gene causing prelingually severe autosomal dominant nonsyndromic hearing loss. J. Gene Med. 2017, 19, e2950. [CrossRef] [PubMed]

277. Kim, K.-Y.; Kovács, M.; Kawamoto, S.; Sellers, J.R.; Adelstein, R.S. Disease-associated Mutations and Alternative Splicing Alter the Enzymatic and Motile Activity of Nonmuscle Myosins II-B and II-C. J. Biol. Chem. 2005, 280, 22769-22775. [CrossRef]

278. Kim, S.-J.; Lee, S.; Park, H.-J.; Kang, T.-H.; Sagong, B.; Baek, J.-I.; Oh, S.-K.; Choi, J.Y.; Lee, K.-Y.; Kim, U.-K. Genetic association of MYH genes with hereditary hearing loss in Korea. Gene 2016, 591, 177-182. [CrossRef] [PubMed]

279. Yang, R.; Li, H.; Zhan, C.X.; Mao, H.Y.; Zhan, T.L.; Zhu, Z.F.; Liu, P.; Yuan, W.L.; Ke, T.; Wang, Q.; et al. c.359T>C mutation of the MYH14 gene in two autosomal dominant non-syndromic hearing impairment families with common ancestor. Chin. J. Med. Genet. 2010, 27, 259-262. [CrossRef]

280. Yang, T.; Pfister, M.; Blin, N.; Zenner, H.P.; Pusch, C.M.; Smith, R.J.H. Genetic heterogeneity of deafness phenotypes linked to DFNA4. Am. J. Med. Genet. Part A 2005, 139A, 9-12. [CrossRef]

281. Choi, B.-O.; Hee Kang, S.; Hyun, Y.S.; Kanwal, S.; Park, S.W.; Koo, H.; Kim, S.-B.; Choi, Y.-C.; Yoo, J.H.; Kim, J.-W.; et al. A complex phenotype of peripheral neuropathy, myopathy, hoarseness, and hearing loss is linked to an autosomal dominant mutation in MYH14. Hum. Mutat. 2011, 32, 669-677. [CrossRef] 
282. Iyadurai, S.; Arnold, W.D.; Kissel, J.T.; Ruhno, C.; Mcgovern, V.L.; Snyder, P.J.; Prior, T.W.; Roggenbuck, J.; Burghes, A.H.; Kolb, S.J. Variable phenotypic expression and onset in MYH14 distal hereditary motor neuropathy phenotype in a large, multigenerational North American family. Muscle Nerve 2017, 56, 341-345. [CrossRef]

283. Pfeffer, G.; Innes, A.M.; Shutt, T.E. Neuropathy due to impaired axonal transport of non-fragmented mitochondria in MYH14 mutation carriers-Authors' reply. EBioMedicine 2019, 49, 25. [CrossRef] [PubMed]

284. Fransson, ̊.; Ruusala, A.; Aspenström, P. The atypical Rho GTPases Miro-1 and Miro-2 have essential roles in mitochondrial trafficking. Biochem. Biophys. Res. Commun. 2006, 344, 500-510. [CrossRef] [PubMed]

285. Hirokawa, N.; Niwa, S.; Tanaka, Y. Molecular motors in neurons: Transport mechanisms and roles in brain function, development, and disease. Neuron 2010, 68, 610-638. [CrossRef]

286. Hollenbeck, P.J. The pattern and mechanism of mitochondrial transport in axons. Front. Biosci. 1996, 1, d91-d102. [CrossRef]

287. Loss, O.; Stephenson, F.A. Developmental changes in trak-mediated mitochondrial transport in neurons. Mol. Cell. Neurosci. 2017, 80, 134-147. [CrossRef] [PubMed]

288. Oeding, S.J.; Majstrowicz, K.; Hu, X.-P.; Schwarz, V.; Freitag, A.; Honnert, U.; Nikolaus, P.; Bähler, M. Identification of Miro1 and Miro2 as mitochondrial receptors for myosin XIX. J. Cell Sci. 2018, 131, jcs219469. [CrossRef] [PubMed]

289. Pathak, D.; Sepp, K.J.; Hollenbeck, P.J. Evidence That Myosin Activity Opposes Microtubule-Based Axonal Transport of Mitochondria. J. Neurosci. 2010, 30, 8984-8992. [CrossRef] [PubMed]

290. Fukumitsu, K.; Hatsukano, T.; Yoshimura, A.; Heuser, J.; Fujishima, K.; Kengaku, M. Mitochondrial fission protein Drp1 regulates mitochondrial transport and dendritic arborization in cerebellar Purkinje cells. Mol. Cell. Neurosci. 2016, 71, 56-65. [CrossRef] [PubMed]

291. Drerup, C.M.; Herbert, A.L.; Monk, K.R.; Nechiporuk, A.V. Regulation of mitochondria-dynactin interaction and mitochondrial retrograde transport in axons. eLife 2017, 6, e22234. [CrossRef]

292. Reddy, P.H. Abnormal tau, mitochondrial dysfunction, impaired axonal transport of mitochondria, and synaptic deprivation in Alzheimer's disease. Brain Res. 2011, 1415, 136-148. [CrossRef] [PubMed]

293. Magrané, J.; Cortez, C.; Gan, W.-B.; Manfredi, G. Abnormal mitochondrial transport and morphology are common pathological denominators in SOD1 and TDP43 ALS mouse models. Hum. Mol. Genet. 2013, 23, 1413-1424. [CrossRef]

294. De Vos, K.J.; Chapman, A.L.; Tennant, M.E.; Manser, C.; Tudor, E.L.; Lau, K.-F.; Brownlees, J.; Ackerley, S.; Shaw, P.J.; McLoughlin, D.M.; et al. Familial amyotrophic lateral sclerosis-linked SOD1 mutants perturb fast axonal transport to reduce axonal mitochondria content. Hum. Mol. Genet. 2007, 16, 2720-2728. [CrossRef] [PubMed]

295. Sadun, A.A. The optic neuropathy of Alzheimer's disease. Metab. Pediatric Syst. Ophthalmol. 1989, 12, 64-68. [PubMed]

296. Berisha, F.; Feke, G.T.; Trempe, C.L.; McMeel, J.W.; Schepens, C.L. Retinal abnormalities in early Alzheimer's disease. Investig. Ophthalmol. Vis. Sci. 2007, 48, 2285-2289. [CrossRef] [PubMed]

297. La Morgia, C.; Barboni, P.; Rizzo, G.; Carbonelli, M.; Savini, G.; Scaglione, C.; Capellari, S.; Bonazza, S.; Giannoccaro, M.P.; Calandra-Buonaura, G. Loss of temporal retinal nerve fibers in Parkinson disease: A mitochondrial pattern? Eur. J. Neurol. 2013, 20, 198-201. [CrossRef]

298. Kersten, H.M.; Danesh-Meyer, H.V.; Kilfoyle, D.H.; Roxburgh, R.H. Optical coherence tomography findings in Huntington's disease: A potential biomarker of disease progression. J. Neurol. 2015, 262, 2457-2465. [CrossRef]

299. Hirokawa, N.; Noda, Y.; Tanaka, Y.; Niwa, S. Kinesin superfamily motor proteins and intracellular transport. Nat. Rev. Mol. Cell Biol. 2009, 10, 682-696. [CrossRef] [PubMed]

300. Tanaka, Y.; Kanai, Y.; Okada, Y.; Nonaka, S.; Takeda, S.; Harada, A.; Hirokawa, N. Targeted disruption of mouse conventional kinesin heavy chain kif5B, results in abnormal perinuclear clustering of mitochondria. Cell 1998, 93, 1147-1158. [CrossRef]

301. Hirokawa, N.; Tanaka, Y. Kinesin superfamily proteins (KIFs): Various functions and their relevance for important phenomena in life and diseases. Exp. Cell Res. 2015, 334, 16-25. [CrossRef]

302. Kanai, Y.; Okada, Y.; Tanaka, Y.; Harada, A.; Terada, S.; Hirokawa, N. KIF5C, a novel neuronal kinesin enriched in motor neurons. J. Neurosci. 2000, 20, 6374-6384. [CrossRef] [PubMed]

303. Nangaku, M.; Sato-Yoshitake, R.; Okada, Y.; Noda, Y.; Takemura, R.; Yamazaki, H.; Hirokawa, N. KIF1B, a novel microtubule plus end-directed monomeric motor protein for transport of mitochondria. Cell 1994, 79, 1209-1220. [CrossRef]

304. Tanaka, K.; Sugiura, Y.; Ichishita, R.; Mihara, K.; Oka, T. KLP6: A newly identified kinesin that regulates the morphology and transport of mitochondria in neuronal cells. J. Cell Sci. 2011, 124, 2457-2465. [CrossRef] [PubMed]

305. Crimella, C.; Baschirotto, C.; Arnoldi, A.; Tonelli, A.; Tenderini, E.; Airoldi, G.; Martinuzzi, A.; Trabacca, A.; Losito, L.; Scarlato, M.; et al. Mutations in the motor and stalk domains of KIF5A in spastic paraplegia type 10 and in axonal Charcot-Marie-Tooth type 2. Clin. Genet. 2012, 82, 157-164. [CrossRef]

306. Goizet, C.; Boukhris, A.; Mundwiller, E.; Tallaksen, C.; Forlani, S.; Toutain, A.; Carriere, N.; Paquis, V.; Depienne, C.; Durr, A. Complicated forms of autosomal dominant hereditary spastic paraplegia are frequent in SPG10. Hum. Mutat. 2009, 30, E376-E385. [CrossRef]

307. Nam, D.E.; Yoo, D.H.; Choi, S.S.; Choi, B.-O.; Chung, K.W. Wide phenotypic spectrum in axonal Charcot-Marie-Tooth neuropathy type 2 patients with KIF5A mutations. Genes Genom. 2018, 40, 77-84. [CrossRef] [PubMed]

308. Liu, Y.-T.; Laurá, M.; Hersheson, J.; Horga, A.; Jaunmuktane, Z.; Brandner, S.; Pittman, A.; Hughes, D.; Polke, J.M.; Sweeney, M.G.; et al. Extended phenotypic spectrum of KIF5A mutations. Spastic Paraplegia Axonal Neuropathy 2014, 83, 612-619. [CrossRef] 
309. López, E.; Casasnovas, C.; Giménez, J.; Santamaría, R.; Terrazas, J.M.; Volpini, V. Identification of two novel KIF5A mutations in hereditary spastic paraplegia associated with mild peripheral neuropathy. J. Neurol. Sci. 2015, 358, 422-427. [CrossRef] [PubMed]

310. Rinaldi, F.; Bassi, M.T.; Todeschini, A.; Rota, S.; Arnoldi, A.; Padovani, A.; Filosto, M. A Novel Mutation in Motor Domain of KIF5A Associated With an HSP/Axonal Neuropathy Phenotype. J. Clin. Neuromuscul. Dis. 2015, 16, 153-158. [CrossRef] [PubMed]

311. Tessa, A.; Silvestri, G.; de Leva, M.F.; Modoni, A.; Denora, P.S.; Masciullo, M.; Dotti, M.T.; Casali, C.; Melone, M.A.B.; Federico, A.; et al. A novel KIF5A/SPG10 mutation in spastic paraplegia associated with axonal neuropathy. J. Neurol. 2008, 255, 1090-1092. [CrossRef]

312. Cuchanski, M.; Baldwin, K.J. Mutation in KIF5A c.610C>T Causing Hereditary Spastic Paraplegia with Axonal Sensorimotor Neuropathy. Case Rep. Neurol. 2018, 165-168. [CrossRef]

313. Füger, P.; Sreekumar, V.; Schüle, R.; Kern, J.V.; Stanchev, D.T.; Schneider, C.D.; Karle, K.N.; Daub, K.J.; Siegert, V.K.; Flötenmeyer, M.; et al. Spastic Paraplegia Mutation N256S in the Neuronal Microtubule Motor KIF5A Disrupts Axonal Transport in a Drosophila HSP Model. PLoS Genet. 2012, 8, e1003066. [CrossRef]

314. Campbell, P.D.; Shen, K.; Sapio, M.R.; Glenn, T.D.; Talbot, W.S.; Marlow, F.L. Unique Function of Kinesin Kif5A in Localization of Mitochondria in Axons. J. Neurosci. 2014, 34, 14717-14732. [CrossRef] [PubMed]

315. Zhao, C.; Takita, J.; Tanaka, Y.; Setou, M.; Nakagawa, T.; Takeda, S.; Yang, H.W.; Terada, S.; Nakata, T.; Takei, Y.; et al. CharcotMarie-Tooth Disease Type 2A Caused by Mutation in a Microtubule Motor KIF1B $\beta$. Cell 2001, 105, 587-597. [CrossRef]

316. Tomaselli, P.J.; Rossor, A.M.; Horga, A.; Laura, M.; Blake, J.C.; Houlden, H.; Reilly, M.M. A de novo dominant mutation in KIF1A associated with axonal neuropathy, spasticity and autism spectrum disorder. J. Peripher. Nerv. Syst. 2017, 22, 460-463. [CrossRef] [PubMed]

317. Lee, J.-R.; Srour, M.; Kim, D.; Hamdan, F.F.; Lim, S.-H.; Brunel-Guitton, C.; Décarie, J.-C.; Rossignol, E.; Mitchell, G.A.; Schreiber, A.; et al. De Novo Mutations in the Motor Domain of KIF1A Cause Cognitive Impairment, Spastic Paraparesis, Axonal Neuropathy, and Cerebellar Atrophy. Hum. Mutat. 2015, 36, 69-78. [CrossRef] [PubMed]

318. Rivière, J.-B.; Ramalingam, S.; Lavastre, V.; Shekarabi, M.; Holbert, S.; Lafontaine, J.; Srour, M.; Merner, N.; Rochefort, D.; Hince, P.; et al. KIF1A, an Axonal Transporter of Synaptic Vesicles, Is Mutated in Hereditary Sensory and Autonomic Neuropathy Type 2. Am. J. Hum. Genet. 2011, 89, 219-230. [CrossRef]

319. Samanta, D.; Gokden, M. PEHO syndrome: KIF1A mutation and decreased activity of mitochondrial respiratory chain complex. J. Clin. Neurosci. 2019, 61, 298-301. [CrossRef]

320. Kaur, S.; Van Bergen, N.J.; Verhey, K.J.; Nowell, C.J.; Budaitis, B.; Yue, Y.; Ellaway, C.; Brunetti-Pierri, N.; Cappuccio, G.; Bruno, I.; et al. Expansion of the phenotypic spectrum of de novo missense variants in kinesin family member 1A (KIF1A). Hum. Mutat. 2020, 41, 1761-1774. [CrossRef]

321. Lo, K.Y.; Kuzmin, A.; Unger, S.M.; Petersen, J.D.; Silverman, M.A. KIF1A is the primary anterograde motor protein required for the axonal transport of dense-core vesicles in cultured hippocampal neurons. Neurosci. Lett. 2011, 491, 168-173. [CrossRef]

322. Karki, S.; Holzbaur, E.L.F. Cytoplasmic dynein and dynactin in cell division and intracellular transport. Curr. Opin. Cell Biol. 1999, 11, 45-53. [CrossRef]

323. Holzbaur, E.L.F.; Vallee, R.B. Dyneins: Molecular Structure and Cellular Function. Annu. Rev. Cell Biol. 1994, 10, 339-372. [CrossRef]

324. Koonce, M.P.; Samsó, M. Overexpression of cytoplasmic dynein's globular head causes a collapse of the interphase microtubule network in Dictyostelium. Mol. Biol. Cell 1996, 7, 935-948. [CrossRef] [PubMed]

325. Goodenough, U.; Heuser, J. Structural comparison of purified dynein proteins with in situ dynein arms. J. Mol. Biol. 1984, 180, 1083-1118. [CrossRef]

326. Goodenough, U.W.; Gebhart, B.; Mermall, V.; Mitchell, D.R.; Heuser, J.E. High-pressure liquid chromatography fractionation of Chlamydomonas dynein extracts and characterization of inner-arm dynein subunits. J. Mol. Biol. 1987, 194, 481-494. [CrossRef]

327. King, S.M. The dynein microtubule motor. Biochim. Biophys. Acta (BBA) Mol. Cell Res. 2000, 1496, 60-75. [CrossRef]

328. Eschbach, J.; Dupuis, L. Cytoplasmic dynein in neurodegeneration. Pharmacol. Ther. 2011, 130, 348-363. [CrossRef] [PubMed]

329. Harms, M.B.; Ori-McKenney, K.M.; Scoto, M.; Tuck, E.P.; Bell, S.; Ma, D.; Masi, S.; Allred, P.; Al-Lozi, M.; Reilly, M.M.; et al. Mutations in the tail domain of DYNC1H1 cause dominant spinal muscular atrophy. Neurology 2012, 78, 1714-1720. [CrossRef] [PubMed]

330. Weedon, M.N.; Hastings, R.; Caswell, R.; Xie, W.; Paszkiewicz, K.; Antoniadi, T.; Williams, M.; King, C.; Greenhalgh, L.; NewburyEcob, R.; et al. Exome sequencing identifies a DYNC1H1 mutation in a large pedigree with dominant axonal Charcot-Marie-Tooth Disease. Am. J. Hum. Genet. 2011, 89, 308-312. [CrossRef] [PubMed]

331. Ramoran, N.; Hart, L.L. Valproic acid in bipolar disorder. Dicp Ann. Pharmacother. 1990, 24, 257-258.

332. Willemsen, M.H.; Vissers, L.E.L.; Willemsen, M.A.A.P.; van Bon, B.W.M.; Kroes, T.; de Ligt, J.; de Vries, B.B.; Schoots, J.; Lugtenberg, D.; Hamel, B.C.J.; et al. Mutations in DYNC1H1 cause severe intellectual disability with neuronal migration defects. J. Med. Genet. 2012, 49, 179-183. [CrossRef]

333. Tey, S.; Ahmad-Annuar, A.; Drew, A.P.; Shahrizaila, N.; Nicholson, G.A.; Kennerson, M.L. Analysis of dynein intermediate chains, light intermediate chains and light chains in a cohort of hereditary peripheral neuropathies. Neurogenetics 2014, 15, 229-235. [CrossRef] [PubMed] 
334. Chen, X.-J.; Levedakou, E.N.; Millen, K.J.; Wollmann, R.L.; Soliven, B.; Popko, B. Proprioceptive Sensory Neuropathy in Mice with a Mutation in the Cytoplasmic Dynein Heavy Chain 1 Gene. J. Neurosci. 2007, 27, 14515-14524. [CrossRef] [PubMed]

335. Dupuis, L.; Fergani, A.; Braunstein, K.E.; Eschbach, J.; Holl, N.; Rene, F.; Gonzalez De Aguilar, J.-L.; Zoerner, B.; Schwalenstocker, B.; Ludolph, A.C.; et al. Mice with a mutation in the dynein heavy chain 1 gene display sensory neuropathy but lack motor neuron disease. Exp. Neurol. 2009, 215, 146-152. [CrossRef] [PubMed]

336. Eschbach, J.; Sinniger, J.; Bouitbir, J.; Fergani, A.; Schlagowski, A.-I.; Zoll, J.; Geny, B.; René, F.; Larmet, Y.; Marion, V.; et al. Dynein mutations associated with hereditary motor neuropathies impair mitochondrial morphology and function with age. Neurobiol. Dis. 2013, 58, 220-230. [CrossRef] [PubMed]

337. Zhao, J.; Wang, Y.; Xu, H.; Fu, Y.; Qian, T.; Bo, D.; Lu, Y.-X.; Xiong, Y.; Wan, J.; Zhang, X.; et al. Dync1h1 Mutation Causes Proprioceptive Sensory Neuron Loss and Impaired Retrograde Axonal Transport of Dorsal Root Ganglion Neurons. CNS Neurosci. Ther. 2016, 22, 593-601. [CrossRef] [PubMed]

338. Schiavon, C.R.; Shadel, G.S.; Manor, U. Impaired Mitochondrial Mobility in Charcot-Marie-Tooth Disease. Front. Cell Dev. Biol. 2021, 9, 35. [CrossRef] [PubMed]

339. Shutt, T.E.; McBride, H.M. Staying cool in difficult times: Mitochondrial dynamics, quality control and the stress response. Biochim. Biophys. Acta (BBA) Mol. Cell Res. 2013, 1833, 417-424. [CrossRef] [PubMed]

340. Glancy, B.; Hartnell, L.M.; Malide, D.; Yu, Z.-X.; Combs, C.A.; Connelly, P.S.; Subramaniam, S.; Balaban, R.S. Mitochondrial reticulum for cellular energy distribution in muscle. Nature 2015, 523, 617-620. [CrossRef] [PubMed]

341. Gong, G.; Song, M.; Csordas, G.; Kelly, D.P.; Matkovich, S.J.; Dorn, G.W. Parkin-mediated mitophagy directs perinatal cardiac metabolic maturation in mice. Science 2015, 350, aad2459. [CrossRef] [PubMed]

342. Song, M.; Mihara, K.; Chen, Y.; Scorrano, L.; Dorn, G.W. Mitochondrial Fission and Fusion Factors Reciprocally Orchestrate Mitophagic Culling in Mouse Hearts and Cultured Fibroblasts. Cell Metab. 2015, 21, 273-286. [CrossRef] [PubMed]

343. Lang, A.; Anand, R.; Altinoluk-Hambüchen, S.; Ezzahoini, H.; Stefanski, A.; Iram, A.; Bergmann, L.; Urbach, J.; Böhler, P.; Hänsel, J.; et al. SIRT4 interacts with OPA1 and regulates mitochondrial quality control and mitophagy. Aging 2017, 9, 2163-2189. [CrossRef] [PubMed]

344. Ashrafi, G.; Schlehe, J.S.; LaVoie, M.J.; Schwarz, T.L. Mitophagy of damaged mitochondria occurs locally in distal neuronal axons and requires PINK1 and Parkin. J. Cell Biol. 2014, 206, 655-670. [CrossRef]

345. Palikaras, K.; Lionaki, E.; Tavernarakis, N. Mechanisms of mitophagy in cellular homeostasis, physiology and pathology. Nat. Cell Biol. 2018, 20, 1013-1022. [CrossRef] [PubMed]

346. Soubannier, V.; McLelland, G.-L.; Zunino, R.; Braschi, E.; Rippstein, P.; Fon, E.A.; McBride, H.M. A Vesicular Transport Pathway Shuttles Cargo from Mitochondria to Lysosomes. Curr. Biol. 2012, 22, 135-141. [CrossRef] [PubMed]

347. McLelland, G.-L.; Soubannier, V.; Chen, C.X.; McBride, H.M.; Fon, E.A. Parkin and PINK1 function in a vesicular trafficking pathway regulating mitochondrial quality control. EMBO J. 2014, 33, 282-295. [CrossRef] [PubMed]

348. Merola, A.; Rosso, M.; Romagnolo, A.; Comi, C.; Fasano, A.; Zibetti, M.; Lopez-Castellanos, J.R.; Cocito, D.; Lopiano, L.; Espay, A.J. Peripheral neuropathy as marker of severe Parkinson's disease phenotype. Mov. Disord. 2017, 32, 1256-1258. [CrossRef]

349. Hernandez Fustes, O.J.; Hernandez Fustes, O.J. Sensory Neuropathy in Parkinson Disease: Electrodiagnostic Evaluation. Neurodiagn. J. 2020, 60, 177-184. [CrossRef] [PubMed]

350. Paul, D.A.; Qureshi, A.R.M.; Rana, A.Q. Peripheral neuropathy in Parkinson's disease. Neurol. Sci. 2020, 41, 2691-2701. [CrossRef] [PubMed]

351. Conradt, C.; Guo, D.; Miclea, A.; Nisslein, T.; Ismail, C.; Chatamra, K.; Andersohn, F. Increased prevalence of polyneuropathy Parkinson's disease patients: An observational study. J. Parkinson's Dis. 2018, 8. [CrossRef] [PubMed]

352. Davis, C.-h.O.; Kim, K.-Y.; Bushong, E.A.; Mills, E.A.; Boassa, D.; Shih, T.; Kinebuchi, M.; Phan, S.; Zhou, Y.; Bihlmeyer, N.A.; et al. Transcellular degradation of axonal mitochondria. Proc. Natl. Acad. Sci. USA 2014, 111, 9633-9638. [CrossRef] [PubMed]

353. Melentijevic, I.; Toth, M.L.; Arnold, M.L.; Guasp, R.J.; Harinath, G.; Nguyen, K.C.; Taub, D.; Parker, J.A.; Neri, C.; Gabel, C.V.; et al. C. elegans neurons jettison protein aggregates and mitochondria under neurotoxic stress. Nature 2017, 542, 367-371. [CrossRef]

354. Choong, C.-J.; Okuno, T.; Ikenaka, K.; Baba, K.; Hayakawa, H.; Koike, M.; Yokota, M.; Doi, J.; Kakuda, K.; Takeuchi, T. Alternative mitochondrial quality control mediated by extracellular release. Autophagy 2020, 1-13. [CrossRef] [PubMed]

355. Hayakawa, K.; Esposito, E.; Wang, X.; Terasaki, Y.; Liu, Y.; Xing, C.; Ji, X.; Lo, E.H. Transfer of mitochondria from astrocytes to neurons after stroke. Nature 2016, 535, 551-555. [CrossRef]

356. Black, J.A.; Waxman, S.G. The perinodal astrocyte. Glia 1988, 1, 169-183. [CrossRef]

357. Verhoeven, K.; De Jonghe, P.; Coen, K.; Verpoorten, N.; Auer-Grumbach, M.; Kwon, J.M.; FitzPatrick, D.; Schmedding, E.; De Vriendt, E.; Jacobs, A.; et al. Mutations in the Small GTP-ase Late Endosomal Protein RAB7 Cause Charcot-Marie-Tooth Type 2B Neuropathy. Am. J. Hum. Genet. 2003, 72, 722-727. [CrossRef]

358. Wong, Y.C.; Ysselstein, D.; Krainc, D. Mitochondria-lysosome contacts regulate mitochondrial fission via RAB7 GTP hydrolysis. Nature 2018, 554, 382-386. [CrossRef] [PubMed]

359. Wong, Y.C.; Peng, W.; Krainc, D. Lysosomal regulation of inter-mitochondrial contact fate and motility in Charcot-Marie-Tooth Type 2. Dev. Cell 2019, 50, 339-354.e334. [CrossRef] [PubMed]

360. Pan, Z.-N.; Pan, M.-H.; Sun, M.-H.; Li, X.-H.; Zhang, Y.; Sun, S.-C. RAB7 GTPase regulates actin dynamics for DRP1-mediated mitochondria function and spindle migration in mouse oocyte meiosis. FASEB J. 2020, 34, 9615-9627. [CrossRef] [PubMed] 
361. Phan, V.; Cox, D.; Cipriani, S.; Spendiff, S.; Buchkremer, S.; O'Connor, E.; Horvath, R.; Goebel, H.H.; Hathazi, D.; Lochmüller, H.; et al. SIL1 deficiency causes degenerative changes of peripheral nerves and neuromuscular junctions in fish, mice and human. Neurobiol. Dis. 2019, 124, 218-229. [CrossRef] [PubMed]

362. Blumkin, L.; Bradshaw, T.; Michelson, M.; Kopler, T.; Dahari, D.; Lerman-Sagie, T.; Lev, D.; Chapple, J.P.; Leshinsky-Silver, E. Molecular and functional studies of retinal degeneration as a clinical presentation of SACS-related disorder. Eur. J. Paediatr. Neurol. 2015, 19, 472-476. [CrossRef]

363. Bradshaw, T.Y.; Romano, L.E.L.; Duncan, E.J.; Nethisinghe, S.; Abeti, R.; Michael, G.J.; Giunti, P.; Vermeer, S.; Chapple, J.P. A reduction in Drp1-mediated fission compromises mitochondrial health in autosomal recessive spastic ataxia of Charlevoix Saguenay. Hum. Mol. Genet. 2016, 25, 3232-3244. [CrossRef] [PubMed]

364. Gentil, B.J.; Minotti, S.; Beange, M.; Baloh, R.H.; Julien, J.-P.; Durham, H.D. Normal role of the low-molecular-weight neurofilament protein in mitochondrial dynamics and disruption in Charcot-Marie-Tooth disease. FASEB J. 2012, 26, 1194-1203. [CrossRef] [PubMed]

365. Irobi, J.; Impe, K.V.; Seeman, P.; Jordanova, A.; Dierick, I.; Verpoorten, N.; Michalik, A.; Vriendt, E.D.; Jacobs, A.; Gerwen, V.V.; et al. Hot-spot residue in small heat-shock protein 22 causes distal motor neuropathy. Nat. Genet. 2004, 36, 597-601. [CrossRef] [PubMed]

366. Kijima, K.; Numakura, C.; Goto, T.; Takahashi, T.; Otagiri, T.; Umetsu, K.; Hayasaka, K. Small heat shock protein 27 mutation in a Japanese patient with distal hereditary motor neuropathy. J. Hum. Genet. 2005, 50, 473-476. [CrossRef] [PubMed]

367. Patra, M.; Weiss, C.; Abu-Libdeh, B.; Ashhab, M.; Abuzer, S.; Elpeleg, O.; Mahajnah, M.; Kessel, A.; Azem, A. A novel variant of the human mitochondrial DnaJ protein, Tid1, associates with a human disease exhibiting developmental delay and polyneuropathy. Eur. J. Hum. Genet. 2019, 27, 1072-1080. [CrossRef] [PubMed]

368. Urban, M.J.; Pan, P.; Farmer, K.L.; Zhao, H.; Blagg, B.S.J.; Dobrowsky, R.T. Modulating molecular chaperones improves sensory fiber recovery and mitochondrial function in diabetic peripheral neuropathy. Exp. Neurol. 2012, 235, 388-396. [CrossRef] [PubMed] 